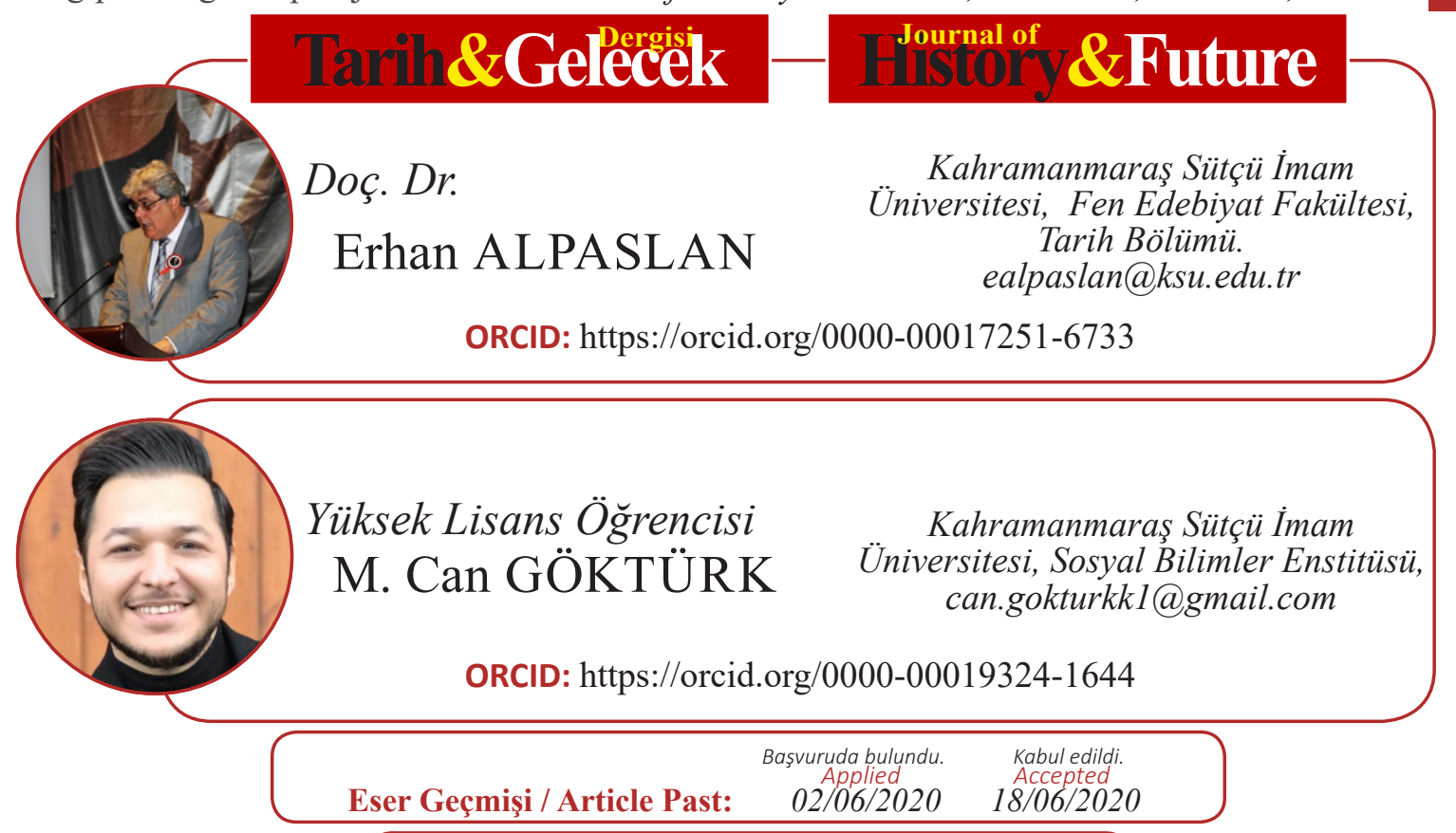

\title{
Maraş’ta Vatan Cephesi (12 Temmuz 1958-27 Mayıs 1960)
}

\author{
Vatan Cephesi (Homeland Front) in Maras (July 12, 1958 - May 27, \\ 1960) \\ $\ddot{O}_{z}$
}

1950 genel seçimleriyle iktidara gelen Demokrat Parti (DP), 1954 seçimlerinden de başarıyla çıkmuştır. 1957 seçimlerinden sonra yurt genelinde iktidar-muhalefet ilişkilerinde cepheleşme eğilimleri başlamıştır. İktidarın özellikle 1958'de uyguladı̆̆ ekonomik politika, geçim sıkıntısının başlamasına neden olmuştur. Bu durum muhalefeti de harekete geçirmiştir. Ekim 1958 yllından itibaren muhalefet partileri de Demokrat Parti'ye karşı ortak hareket etme kararı alarak birleşmişlerdir. Bu siyasi birliktelik karşısında Adnan Menderes, muhalefete karşı kendi taraftarlarını ve tüm vatandaşı "Vatan Cephesi" adı altında birleşmeye çağırmıştır. Yurt genelinde olduğu gibi Maraş'ta da Demokrat Parti il ve ilçe teşkilatının etkili çalışmasıyla Vatan Cephesine yoğun katıllmlar meydana gelmiştir. Maraş'ta DP'ye ve Vatan Cephesine yönelik katılımlar, Maraş'ın yerel gazetelerinden Demokrasiye Hizmet, Kahramanyurt ve Halk Postası'nda isim listesi halinde DP'ye iltihaklar başlığıyla duyurulmuştur.

Bu makalede 12 Temmuz 1958 tarihinde oluşum süreci başlayan ve 27 Mayls askeri müdahalesi ile sona eren Vatan Cephesinin Maraş'taki il ve ilçe teşkilatlanması; Cumhuriyet Arşivi belgeleri ve dönemin basın-yayın organlarında bu konuda yer alan haber ve yazılardan istifade edilerek bir değerlendirme yapılmıştır.

Anahtar Kelimeler: Maraş, Vatan Cephesi, İttihak, Demokrat Parti, Muhalefet

ATIF: ALPASLAN Erhan, GÖKTÜRK M. Can, "Maraş'ta Vatan Cephesi (12 Temmuz 1958-27 Mayıs 1960)", Tarih ve Gelecek Dergisi, 6/2 (Haziran 2020), s. (641-666)

CITE: ALPARSLAN Erhan, GÖKTÜRK M. Can, "Vatan Cephesi (Homeland Front) in Maras (July 12, 1958 May 27, 1960)", Journal of History and Future, 6/2 (June 2020), pp. (641-666) 


\section{Abstract}

The Democrat Party (DP), which came to power with the 1950 General Elections, also succeeded in the 1954 elections. After the 1957 elections, Confrontations started in government and opposition relations throughout the country. The economic policy implemented by the government in 1958 led to the start of financial difficulties. This situation triggered the opposition. In October 1958, opposition parties decided to act jointly against the Democrat Party. On the other hand, Adnan Menderes who leader of Democrat and Prime Minister called on his opponents and all citizens to unite under the name of Vatan Cephesi (Homeland Front) against the opposition. With the effective works of the Democrat Party provincial and district organization in Maras, crowded masses have joined the Vatan Cephesi. Participations to the DP and Homeland Front in Maras were announced under the heading "Participation to the DP" in the local newspapers of "Demokrasiye Hizmet", "Kahramanyurt" and "Halk Postast". In this article, the organization of the province and district of Vatan Cephesi in the Maras, which formation process started on July 12, 1958 and ended with the military intervention on May 27, was evaluated by using the news and articles in the Republic Archive Documents and the media in the period.

Keywords: Maras, Vatan Cephesi ((Homeland Front), Cooperation, Opposition.

\section{Giriș}

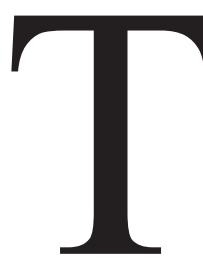

ürkiye'de Cumhuriyetin ilanıyla birlikte iki kere çok partili siyasi hayata geçilmek istenmiş ancak başarısızlıkla sonuçlanmıştır. Türkiye'nin çok partili siyasi hayat deneyiminden sonra İkinci Dünya Savaşı'nı müteakip 7 Ocak 1946'da kurulan Demokrat Parti (DP) ${ }^{1}$ ülke çapında umumi olarak teşkilatlanarak 1950 seçimleriyle birlikte Cumhuriyet Halk Partisi'nin (CHP) 27 yıllık iktidarına demokratik güç ile son vermiştir. ${ }^{2}$ Böylece DP'nin iktidara gelmesiyle Türk siyasi tarihinde iktidar ilk defa seçim yoluyla el değiştirmiş ve DP; demokrasinin ve rejimin geleceğini tayin etme yetisini eline alarak on yıl boyunca iktidarda kalmıştır. ${ }^{3}$ Bu yüzden 1950 seçimleri tarihimizde "Beyaz Devrim” ya da "Kansız Devrim" olarak adlandırılmışırı. ${ }^{4}$

1 Demokrat Partisi 7 Ocak 1946 tarihinde kurularak 85 maddelik parti program neşrolundu; Cumhuriyet, 7 Ocak 1946, Sayı: 22/7682, s.1-3; Cumhuriyet, 8 Ocak 1946, Say1: 22/7683, s. 1-4; Çiftçiyi Topraklandırma Kanunu'ndan sonra Adnan Menderes, Refik Koraltan, Celal Bayar ve Fuat Köprülü CHP içerisinde demokratikleşme ve yenileşmeyi içeren "Dörtlü Takrir" adıyla anılan önergeyi 7 Haziran 1945'te meclise sunmuş reddedilince bu isimler önce basın yoluyla sesini duyurmuş daha sonra DP'yi kurmuşlardır. Cem Eroğul, Demokrat Parti (Tarihi ve İdeolojisi), İmge Kitabevi, 1990, s. 9-12.

21950 genel seçimlerinin oy dağılımına baktı̆̆ımızda mecliste DP; 416 milletvekili ile \%53,59, CHP 69 milletvekili ile \%39,98, Millet Partisi ise 1 milletvekili çıkararak \%3.03 oy alabilmiştir. Ayrıntılı bilgi için bkz. Feroz Ahmad-Bedia Turgay Ahmad, Türkiye'de Çok Partili Politikanın Açıklamalı Kronolojisi (1945-1971), Bilgi Yayınevi, Ankara, 1976 s.66; http://www.ysk.gov.tr/tr/1950-1977-yillari-arasi-milletvekili-genel-secimleri/3007 Erişim Tarihi 03.04.2020.

3 Ahmet Yeşil, Türkiye’de Çok Partili Siyasi Hayata Geçiş, Kültür Bakanlığı, Ankara, 2001, s. 161-163.

4 Sinan Yıldırmaz, "1950 Seçimleri ve Propaganda", Yakın Dönem Türkiye Araştırmaları, T.C. İstanbul Üniversitesi Atatürk İnkllap Tarihi Dergisi, Sayı:6, Yıl:3/ 2004, s. 131. Emel Aslan, Türkiye’nin İç Siyasetinde Demokrat Parti (1950-1960), (Basılmamış Yüksek Lisans Tezi), Ahi Evran Üniversitesi 
1950'den 1954'e giden süreçte DP, yeni rolüne alışmaya çalışmış ve muhalefete sert tavır sergilemiştir. Bu süreçte DP; CHP'nin mevcut mal varlığına el koyması, Orduda CHP'li olup yüksek kademede görev yapan Askeri tasfiye etmesi, Millet Partisi'ni (MP) kapatması, Halkevlerini kapattırması ve Köy Enstitülerinin köy okullarına çevrilmesi gibi uygulamalarda bulunmuştur. ${ }^{5}$ Diğer taraftan DP'nin vergiler ile milli gelir arasında denge kurarak milli geliri arttırması; tarım ve iktisadi politikalar ile kalkınma sürecine girilmesi ve özgürlüklerin genişletilmesi yönünde atmış olduğu adımlar 2 Mayıs 1954 seçimlerine olumlu yansımıştır. ${ }^{6} \mathrm{Bu}$ dönemde alınan ekonomik kararlar halkı da memnun etmiş olacak ki 2 Mayıs 1954 seçimlerinde DP yeni bir siyasi zafer kazanmıştır. ${ }^{7}$ Vatan gazetesi, 1954 seçim sonuçlarını "CHP tam hezimete uğradı" başlığıyla duyururken hezimetin nedenini yaptığı yıkıcı propagandaya bağlamıştır. ${ }^{8}$ Böylece DP, halk nezdinde yerini daha da sağlamlaştırmış ve 1950 genel seçimlerini tesadüfî kazanmadığını kanıtlamıştır.

1954 genel seçimleri sonrasında iktidar-muhalefet arasındaki gerginlik devam etmiş siyasi tansiyon giderek artmıştır. DP'liler, şüphesiz ki Millet Partisi (MP) ve yerini alan Cumhuriyetçi Millet Partisi'ne (CMP) oy veren illeri 30 Haziran 1954'te çıkarılan kanunla suçlayarak bir şekilde cezalandırmış; Kırşehir ilini ilçe haline getirmiş, Malatya'dan da Adıyaman'1 ayırarak ikiye bölmüştür. ${ }^{9} 1954$ yılından itibaren yaşanan siyasal ve sosyal gelişmeler siyasi partiler açısından birçok olumsuzlukları da beraberinde getirmiştir. DP, genel seçim sonuçlarında kazandığı başarının verdiği güvenle adli kaza mercilerinde hâkimler üzerinde baskı kurabileceği hukuki düzenlemeler yapmış bunun yanı sıra basın özgürlüğünü zedeleyecek düzenlemelere gitmiştir. ${ }^{10} \mathrm{Bu}$ bakımdan bu evre oldukça sıkıntılı bir sürecin başlangıcı olmuştur. İktidar partisinin bu dönemdeki bazı uygulamaları başta muhalefet partisi olmak üzere kimi çevrelerden DP'nin totaliter olmakla suçlanmasına yol açmıştır. ${ }^{11} 1956$ yılı itibariyle ekonominin giderek bozulması muhalefetin mitingleri arttırmasına neden olurken bunların basında yer alması iktidar partisini önlem almaya itmiştir. DP, 7 Haziran 1956 ve 27 Haziran 1956'da iki basın yasası değişikliği ile Hürriyet Partisinin (HP) kurulmasına engel olmak istemiştir. ${ }^{12} 7$ Haziran 1956'da 5680 sayılı basın yasasındaki değişikliğe göre: gazete sahibi ve müdür olmak yeni şartlara bağlanırken altı aydan fazla hapis cezasıyla mahkûm olmak mesleğin yürütülmesine engel sayılmıştır. 5680 sayılı basın yasası muhabirleri de kapsarken imzasız yayınlanan yazılarda savcıya 24 saat

Sosyal Bilimler Enstitüsü, Kırşehir 2014, s.39.

5 Iş1l Tuna, "Uşakta Vatan Cephesi”, Atatürk Araştırma Merkezi Dergisi, S.100, C.35, Güz 2019, s. 623; Eroğul, a.g.e., s. 76-77.

6 Cüneyt Arcayürek, Yeni İktidar, Yeni Dönem (1951-1954), Bilgi Yayınevi, Ankara, 1985, s. 63-67.

71954 genel seçimlerinde DP, $\% 58,42$ oy ile mecliste 541 koltuktan 503 milletvekili, CHP ise $\% 35,11$ oy ile meclise 31 milletvekili verebilmiştir. Ahmad ve Ahmad, a.g.e., s. 122; Eroğul, a.g.e., s. 86; http://www. ysk.gov.tr/tr/1950-1977-yillari-arasi-milletvekili-genel-secimleri/3007 Erişim Tarihi 03.04.2020.

8 Vatan, 3 Mayıs 1954, Sayı: 14/4660, s. 1-4.

9 Eroğul, a.g.e., s. 102.

10 Zehra Aslan, "Vatan Cephesi Davası (Kararname, Savunma ve Karar)", History Studies: International Journal of History, Volume 4, Issue 2, July 2012, s. 3-4.

11 Mehmet Biçici, "Gaziantep’te Vatan Cephesi”, Tarih Okulu Dergisi (TOD) Şubat 2020 Yıl 13, Say1 XLIV, s.159.

12 Fahri Yetim, Ulus ve Zafer Gazetelerinin Karşılaştırmalı Incelemeleri (1957-1960), (Basılmamış Doktora Tezi), Gazi Üniversitesi Sosyal Bilimler Enstitüsü, Ankara 2006, s. 65. 
içerisinde bildirme zorunluluğu getirilmiş ve yayın yasaklarının yanı sıra ağır para ve hapis cezası belirlenmiştir. 27 Haziran 1956'da ise 5680 basın yasasındaki değişikliğin yeterli olmadığı düşünülerek 6334 sayılı yasa ile de antidemokratik değişiklikler yapılmıștır. $\mathrm{Bu}$ yasa değişikliği ile radyo veya gazetede yer alan her haber ve yazı siyasi suç unsuru olabilmektedir. ${ }^{13}$ Anlaşıldığ 1 üzere Menderes ve kabinesinin muhalefete, basına ve hatta muhalefete oy veren il ve ilçelere karşı baskı politikası uyguladığı görülmektedir. Basına getirilen bu kısıtlama ve ağır koşullar muhalefetin tepkilerine yol açmıştır.

1957 yılına gelindiğinde Demokrat Parti ile muhalefet arasındaki siyasi gerilim daha da arttı. Bunun üzerine Demokrat Parti, ülke genelinde ve parti içinde yaşanan birtakım gelişmeleri dikkate alarak 1957 yılında erken genel seçim ilan etti. Erken seçim kararı üzerine CHP-Hürriyet Partisi (HP) ve CMP "İş Birliği Toplantısı" yapmış ancak partililerin sandalye kaygılarından dolayı girişimler sonuçsuz kalmıştır. ${ }^{14} 1957$ genel seçim sonuçlarına göre Demokrat Parti üçüncü kez tek başına iktidar olmayı başardı ancak 1954 yılında yapılan genel seçim sonuçları ile karşılaştırıldığında Demokrat Parti'nin oy oranında \% 9,8'lik bir düşüş söz konusu oldu. ${ }^{15} \mathrm{CHP}$, iktidara karşı oy oranını yükseltmesine rağmen bu seçimlerde beklenilen başarıyı gösteremedi. ${ }^{16}$ Ancak muhalefet bu seçimle önemli bir güce eriştiğini ortaya koymuştur. Bu durum başta CHP olmak üzere muhalif partilerin iktidara karşı propagandalarını ve eleştirilerini arttırmasına neden olmuştur. Zira DP'nin bu dönemde yürüttüğü ekonomik politikalar, bütçenin devamlı açık vermesine buna bağlı olarak enflasyon ve zamların artmasına neden olmuştur. Ekonomik alandaki bu gelişmeler halkın yaşam standartlarının düşmesine yol açarken aynı zamanda iktidara karşı bir tepki doğmaya başlamıştır. Dolayısıyla bir taraftan ekonomik gidişattan memnun olmayan halk diğer taraftan da DP'nin antidemokratik uygulamalarını bu memnuniyetsizliği daha da arttırmıştır. Bu durum karşısında DP, azalan prestijini tekrar kazanmaya çalışsa da siyasi alanda muhalefete, hükümeti eleştirecek çok önemli gerekçeler oluşturmuştur. ${ }^{17}$

14 Temmuz 1958'de Irak'ta bir devrim olması muhalefet cephesini tekrar harekete geçirmiş, Adnan Menderes'in diktatörlüğe yöneldiği ve Irak Başbakanı gibi devrilmesi gerektiğini savunmuşlardır. ${ }^{18}$ Irak'ta yaşanan devrim, zaman zaman muhalefetin iktidara karşı kullandığ 1 politik malzeme haline gelmiştir. Bahsi geçen devrimin yanı sıra İsmet İnönü'de Ankara'da yaptığı bir konuşmasında "memleketin iktisadi açıdan mustarip olduğunu ancak sorunların çözülmesi için umumi idare doğru olur, doğruları söylerlerse

13 Mustafa Tokmak, Basın-İktidar İlişkileri Çerçevesinde Demokrat Parti ve Ankara Radyosu, (Basılmamış Yüksek Lisans Tezi), Hacettepe Üniversitesi Atatürk İlkeleri ve İnkılap Tarihi Enstitüsü, Ankara 2007, s. 77-80.

14 Zehra Arslan, “Trabzon'da Vatan Cephesi (12 Ekim 1958-27 Mayıs 1960)”, Karadeniz Araştırmaları Dergisi, S.129, C. 36, Kış 2013, s. 130; Zehra Arslan, "Vatan Cephesi Davası (Kararname, Savunmalar ve Karar)", History Studies: International Journal of History, Volume 4, Issue 2, July 2012, s. 3,19.

15 Yasemin Doğaner, Türk Demokrasi Tarihinde Vatan Cephesi, Siyasal Kitapevi Yayınları, Ankara, 2013, s. 31; Sedef Bulut, "Üçüncü Dönem Demokrat Parti İktidarı (1957-1960): Siyasi Baskılar ve Tahkikat Komisyonu”, Gazi Akademik Bakış, C. 2, Sayı 4, Yaz 2009,s.132-133.

161957 genel seçimlerinin oy dağılımına baktığımızda mecliste DP, 424 milletvekili ile \%48.6, CHP 178 milletvekili ile \%41.4, CMP ise 4 milletvekili çıkararak \%6,5 oy alabilmiştir.http://www.ysk.gov.tr/ tr/1950-1977-yillari-arasi-milletvekili-genel-secimleri/3007 Erişim Tarihi 03.04.2020.

17 Bulut, a.g.m., s. 132.

18 Arslan, “Trabzon'da Vatan Cephesi (12 Ekim 1958-27 May1s 1960)” s.130. 
mesele halledilir." ${ }^{19}$ açıklamasında bulunmuş iktidarın iktisadi politikalarını eleştirmiştir. Ayrıca İnönü İstanbul'da yaptığı bir konuşmasında yine iktidarı hedef alarak "Herkes yarını düşünmektedir. Böyle hayat yaşanılmaz bir hayattır, vatanı yaşayacak hale getirecek CHP müessesesidir." ${ }^{20}$ ifadelerine yer vererek vatandaş1 ve muhalif partileri milli birliğe davet etmiştir. Anlaşılacağı üzere CHP, politik söylemlerine ekonominin kötüye gitmesini de ekleyerek 1957 seçimlerinden sonra iktidara karşı daha sert siyaset yapmaya başlamıştır. Nitekim CHP ile birlikte bazı muhalefet partilerinin bu şekilde davranmasında DP'nin uyguladığı baskı politikası etkili olmuştur. İktidarın baskı politikası karşısında muhalefet partilerinin fiili birleşmesinden başka çareleri kalmamıştır. İlk adımda 16 Ekim 1958'de Türkiye Köylü Partisi (TKP) ile CMP güç birliği kararı almıştır. İki partinin 16 Ekim'de yayınladığı tebliğe CMP adına Osman Bölükbaşı, TKP adın Tahsin Demiray imza atarken birleşme nedeniyle partinin adı Cumhuriyetçi Köylü Millet Partisi (CKMP) olmuştur. ${ }^{21} \mathrm{Bu}$ partileri takiben 24 Kasım 1958 'de HP ile CHP birleşmek için çalışmalara başlamıştır. ${ }^{22}$ Böylece DP meşruiyet krizi içerisindeyken muhalefet, Güç Birliği Cephesi'ni (Milli Muhalefet Cephesi) kurmuştur. Milli Muhalefet Cephesi, safları sıklaştırdıktan sonra hedeflerini belirlemek için bir araya gelmişlerdir. Bu hedefleri, CHP'nin 12-15 Ocak 1959 tarihinde yapılan 14. Kurultayında görüştüler. Kurultayın kabul ettiği İlk Hedefler Beyannamesine göre muhalefet güç birliğinin gayelerini on madde ile şöyle açıklamıştır: Millet Meclisinden başka ikinci bir meclis kurulup partizanlık kaldırılmalı; yüksek yargıçlar kurulu ve anayasa mahkemesi kurularak seçim güvenliği sağlanmalı, basın hürriyeti anayasa güvencesine bağlanırken üniversitelerin özerkliği sağlanmalıdır. ${ }^{23}$ Muhalefet kanadında Güç Birliği'nin oluşumu ve teşkilatlanması iktidarı harekete geçirmiştir. Milli Muhalefet Cephesine karşı Menderes, yurt gezilerine çıkarak muhalefetin birleşmesini, Haçlı Ordusuna benzetmiş ve bu cepheyi ehli salip olarak isimlendirmiş̦tir. ${ }^{24}$ Ayrıca Menderes bu konuda, muhalefetin güç birliğinin amacını bir cephe oluşturup erken seçim yapılmasını sağlamak olduğunu söylerken erken seçimin vatanın refah ve saadetini geciktirmesine ve milletimizin ihtiyaçlarının kesintiye uğramasına neden olacağını söylemiştir. ${ }^{25} \mathrm{Bu}$ siyasi ortamda muhalefet, iktidara karşı Milli Muhalefet Cephesi oluşturmaya yönelik çalışmalar yaparken Menderes, 12 Ekim 1958'de Manisa İl Kongresi'nde Vatan Cephesi'nin oluşturulmasını istemiştir. ${ }^{26}$ Menderes'in muhalefet partilerine karşı oluşturulmasını istediği Vatan Cephesi Zafer Gazetesinde şu manşetle duyurulmuştur: 'Başvekil Adnan Menderes'in Manisa'da

19 Halk Postasl, 9 May1s 1958, Say1: 1288, s. 1.

20 Halk Postasl, 3 Haziran 1958, Sayı: 1308, s. 1.

21 Erdoğan Teziç, 100 Soruda Siyasi Partiler, Gerçek Yayınevi, İstanbul 1976, s. 276-277.

22 Ayşe Aydın, Celal Bayar Dönemi Genel Seçimleri ve TBMM (1950-1960), (Basılmamış Doktora Tezi), Gazi Universitesi Sosyal Bilimler Enstitüsü, Ankara, 2010 s.207-210; Ayşe Elif, Emre Kaya ve Zakir Avşar, "Demokrat Partinin Sivil Toplum Üzerinden Siyasal İletișim Denemesi: Vatan Cephesi Örneği”, The Journal of Academic Social Science Studies, Volume 6, Issue 2, February 2013, s. 401-402; Teziç, a.g.e., s. 279.

23 Eroğul, a.g.e., s. 158.

24 Dilşen İnce Erdoğan, "Güç Birliği Karşısında Adnan Menderes’in Siyasi Manevrası: Vatan Cephesi (Manisa Örneğinde)", Belgi Dergisi, Pamukkale Üniversitesi Atatürk İlkeleri ve İnkılap Tarihi Araştırma ve Uygulama Merkezi Yayını, C. 2, S. 19, Kış 2020, s. 1915.

25 Aydin, a.g.t., s.210-211.

26 BCA, Fon Kodu: 010. 09.Yer No: 212. 656.1, 10.05.1961;Kaya ve Avşar, a.g.m., s.402; Ahmad ve Ahmad, a.g.e., s.185. 
yaptığı konuşma: Nifak Cephesine Karşı Vatan Cephesinin Kurulması Zaruridir!"’. ${ }^{27}$ Başvekil Menderes'in Vatan Cephesi ocağının oluşturulacağını açıklamasının ardından, vatandaşların Demokrat Partiye katılımları artmıştır. DP idarecileri ve DP yanlısı basın, Vatan Cephesinin ocaklarının ülkeye hizmet etmek amacı ile oluşturulduğunu her firsatta tekrarlamış ve demokrasinin bir ürünü olan bu hareketin, kapılarının tüm vatandaşlara açık bulunduğu ve Halk Partisi'nin tahrik dolu politikalarına karşı çıkan herkesin bu cephenin bir üyesi olarak kabul edildiği ifade edilmiştir. ${ }^{28}$ Adnan Menderes'in Manisa İl Kongresi’nde yaptığı konuşmadan sonra ilk Vatan Cephesi Ocağı İstanbul'da açılmıştır. Siyasetten uzak vatandaşları ve vatanın menfaatlerinin DP'nin iktidarda kalması ile sağlanacağına inanan kimseleri tek çatı altına toplamayı amaç edinen Vatan Cephesi, İstanbul'dan sonra yurdun farklı yerlerinde teşkilatlanıp şubelerini açmıştır. ${ }^{29}$ Vatan Cephesi ocaklarının açılması üzerine buna karşılık muhalefet hareketi de Güç Birliği Ocaklarını örgütlemeye başlamıştır. ${ }^{30}$ Muhalefetin oluşturduğu Güç Birliği cephesi genişlerken CHP teşkilatı, yeni ocaklar açarak bu ocaklarda DP iktidarını eleştirmeye devam etmiştir. ${ }^{31}$

DP popülizminin temelini, 1950-1954 döneminde biriken kaynaklar ve geniş diş borçlanma oluşturmuştur. 1954 sonrasında ekonominin hızla bozulması, bu sistemi sürdürecek kaynağın kalmamasına neden olmuştur. Giderek azalan toplumsal desteği gözlemleyen DP, din ve milliyetçilik unsurlarını öne çıkararak "Vatan Cephesi" çağrısında bulunmuştur. ${ }^{32}$ Dolayısıyla DP'nin Vatan Cephesi oluşumunu ortaya atmasındaki sebeplere bakıldığında, en önemli gelişmelerin başında iktidara karşı muhalefet cephesindeki birleşmeler, 1957 seçimlerinde yaşanan oy kaybı ve buna bağlı olarak iktidarın yeni birtakım arayışlar içine girdiği hususu öne sürülebilir. ${ }^{33}$ Zira bu arayış içerisinde kurulması kararlaştırılan Vatan Cephesi, zamanla DP teşkilatı içerisinde yer alan önemli bir yan örgüt konumuna gelecektir.

DP karşısında muhalefet, ancak 1957 seçimleriyle şekillenmiştir. Gerçekten de DP'nin 1957 seçimleriyle birlikte ilk defa oy oranı \%50'nin altına düşmüştür. İktidarın, basın yasasında yeni düzenlemeye gitmesiyle birlikte basının da önemli ölçüde desteğini kaybetmiştir. 1957 seçimleriyle birlikte muhalefet Güç Birliği Cephesini oluştururken Demokrat Parti, iktidarlığın verdiği güce dayanarak özellikle Vatan Cephesi ile birlikte basını ve radyoyu kendi lehine kullanmıştır. Kendi güdümündeki gazeteler ile propaganda faaliyetlerine devam eden DP, Vatan Cephesiyle ilgili haber ve tanıtım faaliyetlerinde; Zafer Gazetesini yetersiz bulmuş radyoyu propaganda aracı olarak kullanmaya başlamıştır. Ankara Radyosunda Vatan Cephesine katılanların isimlerinin okunması, 1 Ekim 1958

27 Hakkı Uyar, Türk Siyasal Yaşamında Cepheleşmelere Bir Örnek Vatan Cephesi, Büke Yayınları, İzmir 2001, s.23.

28 Zehra Arslan, "Siyasilerin Beyanatları Çerçevesinde 27 Mayıs Darbesine Gidiş Süreci (27 Ekim 1957 27 Mayıs 1960)",Türk Dünyası Araştırmaları Dergisi, 2013 / 204, (Mayıs -Haziran),s.51-52.

29 Eric Jan Zürcher, Modernleşen Türkiye'nin Tarihi, Çev. Yasemin Saner Gönen, İletişim Yayınları, İstanbul 1995, s. 348-350.

30 Biçici, a.g.m., s. 161.

31 Aliye Küçükpınar, Maraş Basınında Demokratik Parti (1946-1960), (Basılmamış Yüksek Lisans Tezi) Kahramanmaraş Sütçü İmam Üniversitesi Sosyal Bilimler Enstitüsü, Kahramanmaraş 2019, s.78-79.

32 İlkay Sunar, "Demokrat Parti ve Popülizm”, CDTA, C.8, İstanbul 1983, s. 2083.

33 Muhammed Sarı, "Demokrat Parti Dönemi Basınına Göre İktidar-Muhalefet İlişkileri Açısından 'Vatan Cephesi”, 10. Uluslararası Türk Dünyası Sosyal Bilimler Kongresi, 2012, s. 752. 
tarihinde başlamış 26 Ocak 1960 tarihine kadar okunmaya devam etmiştir. ${ }^{34}$ Radyo'da günlük haber saatinde Vatan Cephesine katılanların isimlerini ve memleketlerini liste halinde okumaya başlamıştır. Devlete ait bir radyonun, partinin yayın organıymış gibi kullanılması muhalefetin ve halkın tepkisine yol açmışıı. Radyodan okumalar o kadar abartılmıştır ki bu duruma vatandaşlar "radyoyu kapatma yoluna giderek" tepkilerini ortaya koymuşlardır. ${ }^{35}$ Vatan Cephesine katılanlar radyoda ilan edilirken, muhalefet partileri radyoyu "partizan radyo" olarak nitelendirmesine ve "Ajans Haberlerini Dinlemeyenler Derneği" kurmalarına neden olmuştur. ${ }^{36}$ Ancak bu durum Vatan Cephesinin ülke genelinde yayılmasını engelleyememiş olacak ki bu cepheye yeni katılımlar devam etmiştir. Diğer taraftan muhalefet partileri, Konya mezarlığından 1200 kişinin isminin Vatan Cephesine katılmış gibi gösterildiğini iddia etmiştir. Ayrıca birçok ilde Vatan Cephesi adıyla iktidarın lehine olumlu haber taşıyan haftalık broşürler bastırılıp halka bedava dağıtılmıştır. ${ }^{37} \mathrm{DP}$ iktidarı, ekonomik ve toplumsal krizin oluşmasıyla birlikte politik bir manevra olarak Vatan Cephesini yaratmıştır. ${ }^{38}$ Nitekim DP bu yolla muhalefeti engellemenin yolunu bulduğunu düşünmüştür. Vatan Cephesine katılanların sayıları ile ilgili rakamlarda tutarlılık yoktur ancak dönemin DP Milletvekili Rıfkı Salim Burçak; Ocak 1959'da Menderes'e çekilen telgraflar 20.000, Vatan Cephesine katılanların sayısı takriben 200.000, sadece Aralık 1959 'da ise bu cepheye katılanların toplam sayısının 973.170 olduğunu ifade etmiştir. ${ }^{39}$

\section{1958 Yılında Maraş'ta Vatan Cephesi}

Adnan Menderes'in Manisa'da Vatan Cephesinin oluşturulmasını istemesinden kısa süre sonra ülke genelinde partilerinden istifa ederek DP ocak ve bucaklarına katılım artmıştır. Özellikle 1957 seçimlerinin hemen ardından Devlet Radyosu, Vatan Cephesi ve bu cepheye kitleler halindeki iltihaklardan bahsederek devamlı ve metotlu propaganda kampanyası başlamıştır. Muhalefet ise buna mukabil Güç Birliği kararına varmış ve safları sıklaştırmıştır. ${ }^{40}$ Aynı şekilde Maraş’ta da muhalif partilerden istifa eden veya bağımsız olan vatandaşlardan DP'ye ve Vatan Cephesi ocaklarına birçok katılım olmuştur. Örneğin CHP Pazarcık İlçe İdare Heyeti Azası Ahmet Güven ve Doğan Aldoğan olmak üzere 7 kişi DP Vilayet İdare Heyeti Başkanı Ahmet Kadığlu'na partiye katılmak için müracaat etmiştir. ${ }^{41}$ Bunların yanı sıra Adnan Menderes'in ülkenin kalkınmasına yönelik yeni projeler ortaya koyması, özellikle köylerin sorunlarını çözüme kavuşturma konusundaki gösterdiği çabası halkın dikkatinden kaçmamış kendisine ve partiye yönelik ilgi ve alakayı arttırmıştır. Dolayısıyla Maraş’ta da partiye yönelik bir hareketlenme görülmüştür. Nitekim

\footnotetext{
34 Sar1; a.g.m., s. 754.

35 Aydın, a.g.t., 211-212.

36 Bilal Tunç, "Türk Siyasi Tarihinde Demokrat Parti Uygulamalarından Vatan Cephesinin Sakarya'daki Yansimaları", Current Research in Social Sciences, Cilt 3, Say1 3, Ocak 2017, s. 155.

37 Mustafa Serhan Yücel, Demokrat Parti, Ülke Kitapları, İstanbul 2001, s. 138.

38 Sinan Yıldırmaz, "Vatan Cephesi: Demokrat Parti'nin Politik Meşruiyet Krizi ve Toplumsal Muhalefeti Kontrol Altına Alma Çabası”, Türkiye’de Siyasal Muhalefet 1923-1980 Makaleler, Der. Ayşegül Komsuoğlu, Bengi Yayınevi, İstanbul 2008, s.175.

39 Rifkı Salim Burçak, On Yllın Anıları (1950-1960), Nurol Matbaacılık, Ankara 1998, s. 605-606.

40 Halk Postasl, 17 Şubat 1958, Say1: 1517, s. 1.

41 Kahramanyurt, 15 Eylül 1958, Sayı:2573, s. 1.
} 
26 vatandaş ile Kavaklı Köyü CMP ocak başkanı Ömer Taşdemir, Baydemirli Köyü CMP ocak başkanı Hasan Yenigül gibi isimler de istifa ederek DP'ye katılmışlardır. ${ }^{42}$ Afşin'in Lorşun köyünden 280'e yakın aileyi temsil eden ve CHP'nin köydeki dayanağı olan 64 kişinin de CHP'den istifa ederek DP'ye geçtiğini şu sözlerle anlatmışlardır: “DP'nin kuruluşu ile vatandaşın nasıl bir değer taşıdığını ve devletin ferlere karşı olan taahhütlerinin sebep ve hikmetini anlamaya başlayarak zaman zaman mensubu olduğumuz CHP'den istifa etmeyi düşünmüştük. Bu vicdan sesimizi açıkladıkça partimizin idarecileri karşımıza geçip sindirilmemizi sağladılar. Ancak DP safına katılmak bir zaruret halinde kendisini hissettirmiştir." ${ }^{33}$ Açıkça görülüyor ki diğer partilere ait ocak ve bucak yöneticileri ve vatandaşların partilerinden istifa ederek DP'ye ve Vatan Cephesi ocaklarına katılması bu cephenin etkili duruma geldiğini göstermektedir. Ayrıca Maraş'ın yerel gazetelerinden Demokrasiye Hizmet, Kahramanyurt ve Halk Postası'nda CHP ve CMP'den istifa ederek DP'ye ve ocaklarına iltihak edenlerin duyurulması diğer vatandaşların da DP'ye ve Vatan Cephesi ocaklarına girmesinde etkili olmuştur. Örneğin Emin Pakdil; "Maraş Demokrat Partisine üç beş ay zarfinda köy ve kazalardan asli ve necip halkımızın partiye girmelerini ilan eden gazeteniz neşriyatından zevk alarak bende bu Vatan Cephesine iltihak etmekle şereflendiğimin yine kıymetli gazetenizle umumi efkâra duyurulmasını sevgiyle arz ederim." ${ }^{44}$ diyerek Maraş'ta CHP ve CMP'ten birçok vatandaşın DP'ye ve Vatan Cephesi ocaklarına geçtiğini ortaya koymaktadır.

27 Ekim 1958 y1lında Devlet Vekili Haluk Şaman, Ziraat Vekili Nedim Ökmen ve DP Genel İdare Kurulu Azası Rıfkı Salim Burçak Maraş'a gelerek Kıbrıs Meydanında halkı selamlamıştır. Nedim Ökmen halka yaptığ 1 konuşmada 1957 genel seçimlerini işaret ederek şu sözleri söylemiştir “Maraş’ta seçimleri kaybetmiş sayılır mıyız? Ben Maraş’ı Demokrat Parti'nin kalesi ve Maraşlıları kahraman muhafızları olarak görüyor tanıyorum. Maraşlılar hiçbir zaman sözleriyle fiilleri arasında yüz seksen derecelik fark bulunanların peşinden gitmeyeceklerine inanıyorum." 45 Gerçekten de DP, 1957 genel seçimlerinde Ankara; Kars, Elâzığ, Malatya, Ordu, Sivas, Tunceli, Uşak, Niğde, Hatay, Tokat, Mardin, Erzincan, Urfa ve Van ile birlikte 23 vilayet kaybetmiş bunlardan bir tanesi de Maraş ${ }^{46}$ olmasına rağmen halk DP'yi büyük bir coşku ve heyecanla karşılamıştır.

CHP ve CMP'ten Vatan Cephesi ocaklarına geçen kişiler basın yoluyla halka duyurulurken ayrıca Adnan Menderes'e de iletilmiştir. Özellikle Pazarcık'ta birçok ocak başkanı istifa edip Vatan Cephesi ocaklarına geçerken vatandaşın da söz konusu partiye geçişi artmıştır. 1958 yılında Maraş'tan Adnan Menderes'e çekilen telgraflarda DP'ye ve Vatan Cephesi ocaklarına kayıtlarda muhalefetin yıkıcı davranışları ve ülkeye zararlarının dokunduğu düşünceleri etkili olmuştur. Örneğin Elbistan Yazı Topallı Köyü Halk Partisi Delegesi Halil Çiftçi, Halk Partisi kongresinde CHP'nin “eski inkârcı ve şef zihniyetini

42 Kahramanyurt, 6 Ekim 1958, Say1: 2593, s. 1.

43 Kahramanyurt, 14 Ekim 1958, Sayı: 2600, s. 1.

44 Kahramanyurt, 27 Kasim 1958, Say1: 2638, s. 1.

45 Kahramanyurt, 27 Ekim 1958, Sayı: 2616, s. 1.

46 Vatan, 28 Ekim 1957, Sayı:18/5902, s. 1-4; Cengiz Şavkılı ve Ali Akyıldız, "Demokrat Parti Dönemi Maraş Basını”, Kahramanmaraş Sütçü İmam Üniversitesi Sosyal Bilimler Dergisi, S.16, C.2, 2019 , s. 767. 
terk etmediğini gördüğünü” söyleyerek DP'ye kayit olduğunu bildirmiştir. ${ }^{47}$ Yine Elbistan Güvercinlik Köyü CHP ocak başkanı Ali Kısa, ocak üyesi Mehmet Bıçak ve Durdu Bıçak benzer sözlerle; muhalefetin inkârcı zihniyetini değiștirmediğini ve yapılan hizmetlere engel olduğunu söyleyerek ocağa kayıtlı 70 kişi ile birlikte Vatan Cephesine geçtiğini telgraf çekerek Menderes'e bildirmiştir. ${ }^{48} 11$ Eylül 1958 tarihinde Göksun kazasının Göynük Köyünden Mehmet Topal; Haydar Kartal, Süleyman Keleş, Sabri Keleş ve 180 arkadaşıyla birlikte CHP'den istifa ederek Vatan Cephesine iltihak ederken radyo ile yayınlanmasını istemişlerdir. ${ }^{49}$ Madenci Nuri İnan kendisini şöyle ifade ederek: "27 senelik sabık iktidar çilesinden bizi kurtaracak olan DP müspet gidişine inandım. Vatan Cephesine 5000 arkadaşım ve mahiyetimle birlikte iltihak ediyoruz." 50 Vatan Cephesini desteklediğini telgraf ile Menderes'e iletmiştir. 5 Aralık 1958'de Ahmet Kadıŏlu, Menderes'e şu telgrafı göndermiştir: Vatan Cephesi kuruldu, nazikane davetiniz üzerine iltihaklar devam ediyor. İstifaları her gün postalıyoruz. Müstafi arkadaşlarımızın radyo ve gazete ile ilanına emir ve müsaadenizi rica ederim..." ${ }_{51} 29$ Aralık 1958'de Mehmet Edizer, Menderes'e çektiği telgrafta kendisini şöyle ifade etmiştir: "İlçemizin Hürriyet Partisi idare heyeti 29.12.1958 günü toplanarak güç birliğinin yolsuz kararlarına karşı ilçe idare heyeti ve 95 parça köylerdeki ve o mahallelerdeki ocaklarımızın iştiraki ile güç birliğine karşı vatan cephesini tercih ederek 6100 seçmenle istifamızı vererek DP'ye kaydımızın icrası ve istifamızın neşrini arz eder hürmetle ellerinizden öperim..." 52

\section{1959 Yılında Maraş'ta Vatan Cephesi}

1959 yılı ocak ayından başlamak üzere Vatan Cephesi ocaklarına ya da DP'ye yeni katılımlar olmuştur. Katılımlar oldukça isimleri liste halinde Maraş'ın yerel gazetelerinde ilan edilmeye devam edilmiştir. Halk Postası gazetesindeki bir haberde: Belediye Meclis üyesi Mehmet Çiftçi ve 19 arkadaşının belediye meclisinin acilen toplanması gerektiği haberine yer vermiştir. Haberin ayrıntısına bakıldı̆̆ında Belediye Meclisinin bu çağrı üzerine toplantının yapıldığı ancak bu toplantı sırasında hoş olmayan olayların cereyan ettiğini belirtmiştir. Buna göre toplantı sırasında gündeme gelen ve müzakere edilen arsa meselesi yüzünden tartışma çıktığı ve bunun üzerine valinin müdahalede bulunduğu hatta tarafgir bir tavır sergilediği bu hareketi ile belediyenin tamamen DP'li yedeklerin eline geçmesini istediği dolayısıyla valinin müfrit bir DP'li ve partizan olduğu anlaşılmıştır ${ }^{53}$ denilerek valinin bu tavrı eleştirilmiştir. 20 Ocak tarihinde ise Halk Postasında Vali beyin bu tutumunun kimi kesimler üzerinde etki yarattığı şehrin önden gelen aileleri arasında yer alan ve yerel siyasette etkin bir rol oynayan Kısakürek grubunun DP'ye geçtiği haberi yer almıştır. ${ }^{54} 1959$ yılında Maraş’ta Vatan Cephesi ocaklarının artmasıyla beraber kırsaldan

\footnotetext{
47 BCA,10.9.0.0.218.677.1.142, 27 Kasım 1958.

$48 \quad$ BCA,10.9.0.0.218.677.1.141, 11 Aralık 1958.

49 BCA,10.9.0.0.218.677.1.433, 13 Eylül 1958.

50 BCA,10.9.0.0.218.677.1.429, 10 Kasim 1958.

51 BCA,10.9.0.0.218.677.1.428, 5 Aralık 1958.

52 BCA,10.9.0.0.218.677.1.139, 29 Aral1k 1958.

53 Halk Postasl, 9 Ocak 1959, Say1: 1486, s. 1.

54 Halk Postası, 20 Ocak 1959 Sayı: 1495, s. 1.
} 
daha fazla katılım olduğu görülmektedir. Katılımların arasında muhalefet partilerinin ocak başkanları da yer almaktadır. Örneğin eski CMP ikinci Başkanı ve Pazarcık İlçe Başkanı Ahmet Ganiyusufoğlu ${ }^{55}$, merkez ilçeye bağlı Şehit Evliya Mahallesi CHP ocak başkanı Yaşar Kükrer ve arkadaşı Yaşar Kapukaya ${ }^{56}$ partilerinden istifa ederek Vatan Cephesi ocaklarına kayıtlarını yaptırmışlardır. Demokrat Parti Genel Merkezine gönderilen telgraflara göre Maraş'a bağlı köy ve kazalardan DP ocak ve bucaklarına katılımlar şu şekilde gerçekleşmiştir: Afşin ilçesine bağlı Kerevin Köyü muhtarı İbrahim Gökdoğan ve 45 arkadaş $^{57}$, Elbistan'ın Kale Köyünden Mevlit Yaşdal ve 48 arkadaş1 $^{58}$, Elbistan'ın İlçe merkezinden Hamit İnanç, Mehmet Özpolat, Osman Mihçı ve 23 arkadaş1 ${ }^{59}$, CKMP İlçe Başkanı Memik Savuş ve idare heyeti kayıtlı 885 arkadaşı ${ }^{60}$ Göksün ilçesinin Kayabaşı Mahallesinden CHP ocak başkanı Memet Doğan ve 35 arkadaş ${ }^{61}$, Elbistan ilçesine bağlı Cela Köyünden İsmet Çeleğen ve 57 arkadaş ${ }^{62}$ partilerinden istifa ederek Vatan Cephesine iltihak etmiştir. Bu iltihaklar Demokrat Parti tarafından memnuniyetle karşılanmıştır. 28 Ocak'ta Ankara'dan dönen Maraş DP'li il Başkanı Ahmet Kadıŏlu, bir basın toplantısı düzenleyerek "Başvekili Adnan Menderes'in yurt içinde açmış olduğu geniş ve büyük bir anlam ifade eden Vatan Cephesine 31 belediye meclisi arkadaşımızın iltihakına müsaade istediğini..." ${ }^{\prime 3}$ Menderes'e telgrafla iletmiştir. 3 Şubat'ta Belediye Meclisi toplanarak Vatan Cephesi taraftarları ile vali bir araya gelerek samimi hasbihal etmişlerdir. Daha sonra ise gündemi ele alan Ahmet Kadıŏlu, "bu memlekette yapılacak her hizmetin şerefi benim olduğu kadar da sizlerindir..." ${ }^{64}$ diyerek hizmetlerin bir kişiye değil herkese ait olduğunu vurgulamak istemiştir.

Halk Postası haberine göre Muhalefet, yurt gezileriyle Vatan Cephesine karşı Milli Muhalefet Cephesini güçlendirmeye çalışmıştır. CHP ile CKMP idare kurulu üyeleri ile bir araya gelerek Vatan Cephesi'ne karşı sonuna kadar mücadele edileceği; bu konuda yeni stratejiler geliştirileceği, karşı propaganda yapılacağı ve halkın konu hakkında doğru bilgilendirilmesi gerektiğini belirtmişlerdir. Nitekim bu konuda başlatılan çalışmaların kısa sürede sonuçları görülmüştür. Bazı sağduyulu vatandaşların olumlu tepkiler göstermesi ve vatandaşların partinin bu yaklaşımını benimsendikleri yine bu haberlerde yer almıştır ${ }^{65}$ Vatan Cephesi ve Milli Muhalefet Cephesi kutuplaşması zaman zaman meclise de taşınmıştır. Yine aynı gazetenin yazısına göre Ankara'daki Meclis Toplantısında CHP'liler "Hürriyet, Hürriyet" diye bağırmışlar, DP'liler de CHP Milletvekillerine "Anarşistler" diye karşılık verince milletvekilleri arasında kavga çıkmıştır. Kavga sonucunda Nüvit Yetkin, Turhan

\footnotetext{
55 BCA,10.9.0.0.218.677.1.404, 2 Şubat 1959.

56 BCA,10.9.0.0.218.677.1.399, 10 Şubat 1959.

57 BCA,10.9.0.0.218.677.1.419, 11 Ocak 1959.

58 BCA,10.9.0.0.218.677.1.403, 3 Şubat 1959.

59 BCA,10.9.0.0.218.677.1. 402, 4 Şubat 1959.

60 BCA,10.9.0.0.218.677.1, 397, 12 Şubat 1959.

61 BCA,10.9.0.0.218.677.1.395, 13 Şubat 1959.

62 BCA,10.9.0.0.218.677.1.392, 15 Şubat 1959.

63 Halk Postasl, 28 Ocak 1959, Sayı: 1502, s. 1.

64 Halk Postasl, 3 Şubat 1959, Sayı: 1507, s. 1.

65 Halk Postasl, 7 Mayıs 1959, Sayı: 1959, s. 1.
} 
Fevzioğlu ve Suphi Baykam'a 4'er oturum meclise girmeme cezası verilmiştir. ${ }^{66} \mathrm{Bu}$ olay sonrası CHP tarafından yapılan açıklamada partinin tutumunun değişmeyeceği ve bütün meşru imkânlar ölçüsünde mücadele edileceği söylenmiştir. ${ }^{67}$

Halk Postası gazetesinde "DP İl Başkanının keyfi arzusu ile 1-2 aydır Ankara' da tutulan Valinin yerine hala bir yenisinin atanmadığı, Maraş'ta bütün işlerin aksamaya başladığı... "68 haberine manşette geniş yer verilmiştir. Yaşanan olayların şiddetlenmesinden dolayı Başvekil Adnan Menderes kendi imzası ile yaptığı açıklamalarda kimsenin incitilmemesini istemiştir. ${ }^{69}$ Menderesin yaptığı bu açıklamalar, ülke siyasetinde artan gerginliği azaltmaya yönelik siyasi bir manevra olarak görülse de iç politikaya yeni bir hava getireceği umudunu da arttırmıştır. Bu girişimler siyasetteki tansiyonu düşürse de kısa bir süre sonra çatışma yeniden alevlenmiştir. Bu cepheleşmenin bir sonucu olarak zaman zaman çok müessif olaylar da yaşanmıştır. Bazen her iki parti mensupları arasında ortaya çıkan ihtilaflar bir çatışmaya da dönüşmüştür. Zira Sarız'da DP'liler tarafından CHP üyelerine ateş açılması gibi haberler kısa zamanda basında yer almıştır. ${ }^{70}$

Maraş'ta Vatan Cephesi ocaklarına veya DP teşkilatına katılımlarla ilgili DP il ve ilçe teşkilatının yanında Menderes'e telgraflar çekildiği görülmektedir. Özellikle Elbistan'da Mayıs 1959 tarihi itibariyle Vatan Cephesine katılım artmıştır. Örneğin Elbistan Köprübaş1 Mahallesinden İhsan Özer, Menderes'e yazdığı telgrafta şöyle demiştir: “Aziz vatanımızın kalkınması hususunda gösterdiğiniz başarının bayramı olarak mensubu olduğumuz CHP'den istifa ederek 24 arkadaşımla DP Ocaklarına kayıt olduğumuzu arz ederim..." "ᄁ1 Yine Elbistan'da Duran Karcı ve Ökkeş Kut, 23 arkadaşıyla birlikte Halk Partisinden istifa ederek DP'ye kayıt olduklarını başvekile bildirmiştir. ${ }^{72}$ DP Elbistan İlçe Reis'i Hasan Paksoy'un Menderes'e çektiği telgrafta şu ifadelere yer vermiştir: "Elbistan ilçemize bağlı Şireşan Köyünden Veli Yılmaz, Şireşanlı köyü muhtarı ve Halk Partisi ocak başkanı ile birlikte 249 vatandaşın Vatan Cephesine iltihak ettiklerini arz ederim."73 30 Mayıs 1959'da Menderes'e gönderdikleri telgraf ile Elbistan merkez ilçesine bağlı Ali Güneş ve Mehmet Güneş'le birlikte 7 arkadaşı CHP'den istifa ederek Vatan Cephesi ocaklarına kayıtlarını yaptırdıklarını bildirmişlerdir. ${ }^{74} 1959$ yılında Maraş'ta Vatan Cephesi ocaklarına ve DP teşkilatına kayıt olan vatandaşların çektiği telgraflarda muhalefetin ülkeye zararının dokunduğunu özellikle CHP'nin Ege seyahati ve burada yaşanan olayların kendilerini çok rahatsız ettiğini ve bu itibarla tepkilerini ortaya koymak için CHP'den istifa ettiklerini dile getirmişlerdir. CHP'nin Ege seyahati için ilk başlanılacak yer olarak Uşak seçilmiştir. Ancak İsmet İnönü'nün Ankara' dan trene binmesi sivil vatandaşlar, polisler ve jandarmalar tarafindan engellenmek

\footnotetext{
66 Halk Postasl, 15 Mayıs 1959, Sayı: 1583, s. 1.

67 Halk Postasl, 16 Mayıs 1959, Sayı: 1584, s. 1.

68 Halk Postasl, 21 Mayıs 1959, Sayı: 1588, s. 1.

69 Halk Postasl, 25 Mayıs 1959, Sayı: 1591, s. 1.

70 Halk Postasl, 19 Ağustos 1959, Say1: 1661, s. 1.

71 BCA,10.9.0.0.218.677.1.135, 14 May1s 1959.

72 BCA,10.9.0.0.218.677.1.134, 22 May1s 1959.

73 BCA,10.9.0.0.218.677.1.133, 24 May1s 1959.

74 BCA,10.9.0.0.218.677.1.132, 30 Mayıs 1959.
} 
istenmiş dolayısıyla yurt gezisi hadiseli başlamıştır. ${ }^{75}$ Gerçekten de Nisan 1959 yılında İsmet İnönü, Büyük Taarruz sırasında Yunan Başkomutanı Trikopis'in esir alındığı ve DP'nin kalelerinden biri olan Uşak'ta Ege seyahatini başlatması DP'nin ve DP'li vatandaşların büyük tepkisini çekti. ${ }^{76}$ Basının "Büyük Ege Taarruzu" olarak adlandırdığ 1 bu gezide ${ }^{77} \mathrm{DP}$ Uşak İl Binası önünde "İsmet Paşa çok yaşa!” nidaları atılması ve İsmet İnönü’nün Uşaktan ayrılırken tren garında vatandaşlar tarafından taşlanması iktidar-muhalefet ilişkilerini gerdi. ${ }^{78}$ CHP'nin devam eden seyahatinde Çanakkale'nin Geyikli bucağına gitmek istemiş jandarma ve asker girmesine izin vermemiştir. CHP Milletvekili İbrahim Saffet Onay ve Dâniş Yurdakul; İçişleri Bakanı, Çanakkale Valisi ve savcısına telgraf çekerek seyahate engel olunduğunu bildirmiş ancak gezi gerçekleştirilememiştir. ${ }^{79}$ Siyasi ortamın giderek gerginleştiği bu zamanda Kayseri Yeşilhisar' da CHP ilçe başkanı ile DP Belediye Başkanı arasında silahlı hadise yaşanmış İnönü Kayseri'ye gidip meseleyi kendisi araştırmak istemiştir. Kayseri Valisinin İnönü’ye gelmemesini telgraf ile bildirmesine rağmen İnönü'nün gezisi engellenememiştir. ${ }^{80}$ Bu olaylar ülke genelinde kutuplaşmayı arttırdığı gibi Maraş’ta da etkisini göstermiştir. Örneğin Elbistan'ın Güneşli Mahallesinden Durdu Kilitçi, Hüseyin Kilitçi ve Mehmet Gözbebek: "CHP'nin son ege seyahatinin yıkıcı hareketlerini beğenmediğimizden bu partiden istifa ederek Vatan Cephesine 10 kişilik ailemizle birlikte iltihak ettiğimizi hürmetlerimizle arz ederiz..."\$1 diyerek çektikleri telgraf ile bu durumu bizzat Adnan Menderes'e de bildirmişlerdir. Aynı şekilde Elbistan'ın Fakıoğlu Köyünden Mustafa CHP Ocak İdare Heyeti Adına Mehmet Kuş, 2 Haziran 1959'da Menderes'e göndermiş olduğu telgrafta "CHP Genel Başkanı ve arkadaşlarının son ege seyahatindeki memleket işlerini baltalayıcı ve nizam bozucu hareketlerini beğenmediklerini, bizden başka CHP'li kalmayan köyümüzde ocağımızı kapatarak Vatan Cephesine iltihak ettiğimizi ve köyümüzde muhalif kalmadığını hürmetlerimizle arz ederiz." "82 demiştir. Anlaşıldığı üzere muhalefetin Ege seyahatindeki yaşanan olaylar ve İnönü'nün propagandası yurt genelinde olduğu Maraş’ta da birtakım tepkilerin artmasına yol açmış ve dolayısıyla Vatan Cephesine de katılımı arttırmıştır. Halk tarafından muhalefetin yaptığı propaganda "yıkıcı", "nifak", "bozguncu" olarak görülmüştür. Ayrıca Elbistan'da Vatan Cephesinin kadınlar kolu oluşturulmuştur. Şimdiye kadar hiçbir partiye kayıtlı olmayan kadınlarca oluşturulan Elbistan DP Kadınlar Kolu'nda Başkan Muazzez Konuksal, müteşebbis üyeler ise Naşide Soylu, Müeyyet Atuk ve Feriha Özyurt olmuştur. ${ }^{83}$ Haziran 1959'da Elbistan DP Kadınlar Kolu Başkanı Muazzez Konuksal Menderes'e gönderdiği telgrafta isim listesi halinde CHP'den istifa ederek ve bağımsız olarak 42 Kadının DP'ye katılmak için başvurduklarını

Halk Postasl, 25 Nisan 1959, Say1: 1561, s. 1.

Süleyman İnan, Demokrat Parti Dönemi (1950-1960), Yakın Dönem Türk Politik Tarihi, Anı Yayıncılık, Ankara 2008, s. 119.

Küçükpınar, a.g.t., s.84.

Tuna, a.g.m., s. 635.

Küçükpınar, a.g.t., s. 85.

Halk Postası, 7 Nisan 1960, Sayı: 1867, s. 1.

BCA,10.9.0.0.218.677.1.131. 1 Haziran 1959.

BCA,10.9.0.0.218.677.1.130. 2 Haziran 1959

BCA,10.9.0.0.218.677.1.137, 20 Mart 1959. 
ve kayıtlarının yapıldığını bildirmiştir. ${ }^{84}$

Maraş'ın Göksun ilçesinde de Vatan Cephesi ocaklarına ya da DP teşkilatına birçok katılım olmuştur. Göksun'un Gücüksu Köyü CHP ocak başkanı Abidin Özden, Menderes'e gönderdiği telgrafta "Maraş Millet Vekillerine kul köle olmaktan kurtulmak için 50 seçmenimizle birlikte Cumhuriyet Halk Partisinden istifa ederek Demokrat Partiye intisap ettiğimizi arz ederiz..." ${ }^{85}$ demiştir. Ayrıca Göksun ve köylerinde CHP ocakları kapatılarak Demokrat Parti teşkilatlarına katılanlar olmuştur. Örneğin Büyükçamurlu Köyü CHP ocak başkanı Adil Akdemir, köyde bulunan CHP ocağının kapatılarak Demokrat Parti safina geçtiklerini Menderes'e iletmiştir. ${ }^{86}$ Yine Göksun Yoğunoluk Köyü CHP ocak başkanı Mehmet Ordu, köydeki CHP ocak teşkilatının kapatılarak 50 seçmenle birlikte Vatan Cephesine iltihak ettiğini Menderes'e bildirmiştir. ${ }^{87}$ Görüldügü üzere Maraş ve İlçelerinde Demokrat Partinin yaptığ 1 siyasi faaliyetler kapsamında önemli ölçüde desteğin devam ettiği anlaşılmaktadır. Bunun en bariz yansımalarından biri de partinin öncülüğünde kurulmuş olan Vatan Cephesine katılımlarla gerçekleşmiştir. Ancak şunu da ifade etmek gerekir ki aynı yılın ağustos ayında yaşanan parti içerisindeki siyasi kavgalar hem partiyi hem de Vatan Cephesinin durumunu da olumsuz yönde etkilemiştir. Bu durumla ilgili haberler artık yerel basında yer almaya başlamıştır. Nitekim Halk Postası Gazetesi haberine göre ağustos ayında Vatan Cephesinden bazı istifalar gerçekleşmiştir. Örneğin DP İkinci Başkanı ve Belediye Meclis Üyesi Ahmet Dinçer, Belediye üyelerinden Mustafa Türegün, Ahmet Öncel, Talip Aydın ve Ferit Tarhan DP'li ileri gelenlerinin tutumlarını beğenmediklerini beyan ederek istifa etmiştir. ${ }^{88}$

\section{1960 Yılında Maraş'ta Vatan Cephesi}

Maraş'ta 1 Ocak 1960 tarihi itibariyle muhalefet partilerinden bilhassa CHP'den yeni istifalar gerçekleşirken DP teşkilatına ya da Vatan Cephesi ocaklarına yeni kayıtlar olmuştur. Yine ocak başkanları ve beraberinde bazı aileler topluca DP'ye ya da Vatan Cephesi ocaklarına geçmiştir. Örneğin Nurhak Nahiyesi CHP ocak başkanı ve Muhtarı Murat Çakıroğlu, Karamanlı ve Başdervişli CHP ocak başkanı ve Muhtarı ile Andırın'ın Pınarbaş1, Maraş'ın Yürükselim Mahallelerinden toplam 207 vatandaş ailesiyle birlikte CHP'den istifa ederek DP'ye kayılt olmuştur. ${ }^{89}$ Gün geçtikçe Maraş'ta Vatan Cephesine yeni kayıt olanların sayısında bir artış gerçekleşmiştir. 1 Ocak 1960 tarihinde Elbistan'ın Nurhak nahiyesinden Muhtar Derviş Çimen ve CHP ocak başkanı Ali Doğan ve 128 arkadaşı; Andırın Pınarbaşı mahallesinden Orhan Özkan ve 9 arkadaşı, şehir merkezinden Kerim Yöreş ve 5 kişilik aile efradı, Karaman köyünden Mehmet Gürdal ve 5 arkadaşı, Baş Dervişli köyü muhtarı Halil Yoldaş ve 10 kişilik aile efradı ile toplam 157 kişi CHP'den

\footnotetext{
84 BCA,10.9.0.0.218.677.1.129, 3 Haziran 1959.

85 BCA,10.9.0.0.218.677.1.212, 5 Şubat 1959.

86 BCA,10.9.0.0.218.677.1.204, 9 Mart 1959.

87 BCA,10.9.0.0.218.677.1.205, 6 Mart 1959.

88 Halk Postasl, 18 Ağustos 1959, Say1: 1660, s. 1.

89 Demokrasiye Hizmet, 6 Ocak 1960, Say1: 34/2617, s. 1.
} 
istifa ederek DP'ye kayıt olmuştur. ${ }^{90}$ Diğer taraftan 1960 y1lı itibariyle Maraş'ta CMP'den de istifalar artmıştır. Örneğin Merkez kazaya bağlı Büyük Sır köyünden CMP ocak başkanı Osman Bilgiç ve 32 arkadaşı, partilerinden istifa ederek DP'ye kayıt olduğunu Menderes'e telgraf ile bildirmiştir. ${ }^{91}$ Merkez kazaya bağlı Kafarlı köyünden CMP ocak başkanı Duran Sarı ile 41 arkadaşı partilerinden istifa ederek DP saflarına geçtiklerini Adnan Menderes'e bildirmiştir. ${ }^{92}$ Elbistan'ın Solucak Köyünde Nasır Gündoğan ve 286 arkadaşının CHP'den istifa ederek Vatan Cephesine iltihak ettiğ $i^{93}$ liste halinde halka duyurulmuştur. Ayn ilçeye ait Akçaşar Köyünden Memov Terkivatan ve 92 arkadaşı CHP'den istifa ederek DP safına geçmiştir. Bu kişilerin DP İl Başkanlığına yazdığı dilekçe de şu ifadeler yer almıştır: "DP ve onun hükümleri başta sayın Başvekilimiz Adnan Menderesin memleket sathında çalışmaları ve biz köylülerin ve köyün kalkınmasındaki faaliyetleri karşısında mensubu bulunduğumuz CHP'de daha fazla kalmayı bir ihanet saydığımızdan bu partiden istifa ederek DP Akçaşar Ocağına kayıt olduğumuzu ve buna dair isim ve imzalarımızı sunduğumuzu arz ederiz." ${ }^{94}$ CHP'de yaşanan bu istifalar ve bunun haber olarak yerel basına yansıması tamamıla propaganda amaçlı yapılırken bunun kitleler üzerinde de etkileri kısa zaman içerisinde gözükmeye başlamıştır. Zira vatandaşlar yapılan propagandaların etkisi altında hareket etmiş kimi bölgelerde bireysel kimi bölgelerde de toplu olarak istifa yoluna gidilmiştir. Yerel siyasetçilerin hareket ve tavırları da seçmen kitlesinin ne yöne savrulacağını ve nasıl hareket edeceğini belirleyen önemli bir unsur olmuştur. İstifa dilekçeleriyle birlikte istifa edenlerinin isimlerinin liste halinde gazetelerde yer alması iltihakların vatandaşa ulaştırılmasını sağlamıştır. Dolayısıyla bu durumun yerel siyasette bir domino etkisi yapması kaçınılmaz olmuştur. Nitekim bu haberler yayıldıkça CHP'den ve diğer muhalif partilerden istifa edenler Demokrat Partiye yönelmiştir. Bu durum karşısında muhalif partiler, basın ve radyonun iktidar tarafından baskı altında tutulduğunu ve muhalefete daha az yer verildiğini söylemiştir. Nitekim Halk Postasında yer alan bir habere göre iktidarın yine basını kontrol altına alarak muhalefetin çalışma alanlarının daraltıldığ eleştirilmiştir. Gözcü rumuzlu vatandaş kendisini şöyle ifade etmiştir: "Muhalefetin çalışma imkanları daraltarak radyoyu tek taraflı olarak kullanmak ve basını yıldırmak gibi her türlü menkıbe vasıtalarını işlemez hale getirmek Demokrat Partinin prensibi haline gelmiştir." 95 DP iktidarının basın ve radyoyu kendi menfaatine uygun kullanması muhalefete daha az yer vermesi Vatan Cephesine katılımın artmasına neden olmuştur. Örneğin Demokrasiye Hizmet gazetesinde CHP mebusu Emin Soysal, Menderesin 1952 ve 1955 yıllarında yaptığı açılamalarda muhalefette yer alan partilere mensup mebusların sözlerine de radyolarda ve basında yer verileceği vaadinde bulunduğunu hatırlatmış ancak hali hazırda iktidarın muhalefete böyle bir hakkı tanımadığını ve dolayısıyla iktidar partisinin bu konuda çok da iyi niyetli olmadıklarını belirtmiştir. ${ }^{96}$

\footnotetext{
90 BCA,10.9.0.0.218.677.1.349, 1 Ocak 1960.

91 BCA,10.9.0.0.218.677.1.348, 9 Ocak 1960.

92 BCA,10.9.0.0.218.677.1.347, 11 Ocak 1960.

93 Demokrasiye Hizmet, 13 Ocak 1960, Sayı: 34/2633, s. 1.

94 Demokrasiye Hizmet, 13 Ocak 1960, Sayı: 34/2633, s.1.

95 Halk Postasl, 30 Ocak 1960 Sayı: 1815, s. 1.

96 Demokrasiye Hizmet, 10 Şubat 1960, Sayı: 34/2657, s. 1.
} 
Halk Postası ve Demokrasiye Hizmet gazetelerine göre 1960 yılında DP iktidarının gerek on yıllık icraatını gerek Adnan Menderes'in vatandaş ile alakasını savunarak Vatan Cephesine üye olan vatandaşların sayısı giderek artmıştır. Başvekil Menderes'in yurt içindeki gezileri, vatandaşın üzerinde olumlu yönde tesirinin devam etmesinde etkili olmuştur. Nitekim Başvekil Ankara siyasetinden zaman buldukça Anadolu'da şehir ziyaretlerine devam etmiş ve halkın desteğini almaya çalışmıştır. Parti başkanının bu şehir ziyaretlerinin de halk nazarında çok olumlu neticeler doğurduğu görülmektedir. Denilebilir ki DP ocak ve bucak teşkilatına katılımların artmasında Adnan Menderes'in il ve ilçe gezilerinin büyük etkisi olmuştur. Örneğin 12 Şubat 1960'ta Adnan Menderes'in Maraş’a gelmesiyle Bertiz Nahiyesi CHP ocak başkanı Hacı Köşker, 30 arkadaşıyla partisinden istifa ederek DP'ye geçmiştir. DP Vilayet İdare Heyeti Reisliğine yazdıkları yazıda kendilerini şöyle ifade etmişlerdir: "Muhterem Başvekilimizin Maraş'a gelip nurlu yüzünü gördükten sonra ve Kasım Gürleğin hala binilecek omuz aradığını gördügümüz için senelerdir CHP'ye hizmet ettiğimiz için üzüntü duyduk. Şimdi CHP'den istifa ederek Sayın Adnan Menderes'in yapıcı ellerinde istikbale emniyetle bakan DP'ye kaydımızın yapılmasını rica ederiz." ${ }^{97}$ Menderes'in Maraş'a 12 Şubat kurtuluşunda ziyareti birçok vatandaşın DP'ye kayıt olmasında etkili olmuştur. Maraş ve ilçelerinden muhalefet partisine bağlı kişilerin DP'ye katılmalarına yönelik Menderes'e çektikleri telgraflarda iktidar partisinin memlekete hizmet için "samimiyetle çalıştığı inancı" ve "muhalefetin propagandalarının ülkeye zararı" vurgulanmıştır. Ramazanoğulları ailesinden Ali Aras 60 kişilik efradı ile "Başvekilimizin 12 Şubat kurtuluşunda Maraş'1 ziyareti ve dört saat istirahat etmeden şehrin ve memleketin işleriyle mütemadi süratle ilgilenmesi gönüllerimizi fethetti" diyerek CHP'den istifa edip DP'ye kayıt olmuştur..$^{98}$ Yine 16 Şubat 1960 yılında Çiftçi ve Fabrikatör Osman Arıkan, Menderes'i desteklediğini belirten telgraf çekerek bir kere daha Maraş'a gelmesi temennisinde bulunmuştur. ${ }^{99}$ Dr. Remzi İnce'de Menderes'in Maraş'1 ziyaretinden etkilenerek DP safına geçtiğini duyurmuştur. ${ }^{100}$ Menderes'in Maraş'a ziyaretinden etkilenen Mustafa Ramazanoğlu, akrabaları ve dostlarıyla birlikte kimi bağımsız kimi ise CHP'den olmak üzere 430 kişi DP'ye geçmiştir. ${ }^{101}$ Bunların yanı sıra bireysel hareket eden kimi vatandaşlar parti değiştirmeyi bir gösteriye dönüştürmüsslerdir. Maraş’ta Mali Müşavir olan Hacı Ekrem Beyazıt CHP'den istifa ederek DP'ye kayıt olduğunu gazetede ilan verilerek duyurulmasını rica etmiştir. ${ }^{102}$ Diğer muhalif partililerden de başta ocak başkanları olmak üzere çok sayıda vatandaş partilerinden istifa etmişlerdir. Kurtuluş Bayramı sonunda 83'ü CKMP'den olmak üzere DP'ye 814 vatandaş kaydolmuştur. Maraş DP İl Başkanı Enver Kadıoğlu, Ankara'ya yazdığı yazıda durumu şöyle açıklamıştır: "Nifak Cephesinden Vatan Cephesine 12 Şubat 1960 tarihinden sonra iltihak edenlerin sayıs1 814'ü bulmuştur. Listeyi takdim ediyoruz, bilgilerinize arz ederiz." ${ }^{103}$ Nitekim görülüyor ki İl Başkanları, yeni kayıt olanları hem gazetede duyurmuş hem de Adnan Menderes'i bilgilendirmiştir. Ayrıca DP'ye

\footnotetext{
97 Demokrasiye Hizmet, 23 Şubat 1960, Sayı: 34/2667, s. 1.

98 BCA,10.9.0.0.218.677.1.345, 16 Şubat 1960.

99 BCA,10.9.0.0.218.677.1.344, 16 Şubat 1960.

100 BCA,10.9.0.0.218.677.1.343, 23 Şubat 1960.

101 BCA,10.9.0.0.218.677.1.340. 25 Şubat 1960.

102 Demokrasiye Hizmet, 23 Şubat 1960, Say1: 34/2667, s. 1.

103 Demokrasiye Hizmet, 27 Şubat 1960 Sayı: 34/2671, s. 1.
} 
geçen önemli kişiler Ankara Radyosunda duyurulmuş ve Adnan Menderes ile aralarında geçen telgraflar okunmuştur. Örneğin Hacı Ahmet Pakdil'in Menderes'e yazdığı telgraf Ankara Radyosunda okunurken kendisini şu şekilde ifade etmiştir: "Bazı gazetelerin icraatlarından ve inkârcı neşriyatından üzüntü ve mahcubiyet duyduğunu belirtmiş ve tarafsızlıktan ayrılmaya karar verdiğini Demokrat Partiye kabulünü dilemiştir." 10412 Şubat itibariyle muhalif partilerden veya bağımsız vatandaşlardan Vatan Cephesine katılım artmışsa da DP'liler iltihak propagandasını tasvip etmemiştir. Halk Postası haberine göre DP'liler şu ifadeleri kullanmışlardır: "Vatan Cephesini başarıya götürecek olanlar iltihaklar değil, partinin sevk ve idaresini ele alanlara seçmen vatandaşın besleyeceği güvendir." 105 Örneğin Maraş'ın Duraklı Mahallesinden 44, ${ }^{106}$ Yusuflar Mahallesinden 94, ${ }^{107}$ Mağaralı Mahallesinden 13, Kayabaşı Mahallesinden 10, Divanlı Mahallesinden 2, Gazipaşa Mahallesinden 6, Yürükselim Mahallesinden $5^{108}$ kişi aileleriyle birlikte DP'ye katılmıştır. Bunun yanı sıra Demokrasiye Hizmet gazetesine göre 812 kişi daha partilerinden istifa ederek Vatan Cephesine katılmıştır. Bunlardan Türkoğlu kazası 326, şehirden 143, merkez köylerden 71, Pazarcık'tan 178, Andırından 10, Afşsin'in Soğucak Köyünden 84 vatandaş daha DP'ye geçmiştir. ${ }^{109}$

Demokrasiye Hizmet gazetesinin haberine göre Adnan Menderes, 1 May1s 1960 tarihinde bir radyo konuşması yapmış ve muhalefeti eleştirmiştir. Ankara'da ve İstanbul' da meydana gelen öğrenci olayları, İsmet İnönü'nün Kayseri ziyaretinde yaşanan olaylar ve Tahkikat Komisyonunun kurulması iktidar-muhalefet ilişkilerinin de uzlaşılamaz bir kriz yaratmıştır. Menderes yaşanan olayları işaret ederek bunların siyasi bir suikast girişimi olduğunu ve seçimsiz iktidara gelme teşebbüsünde olunduğunu belirtmiştir. ${ }^{110}$

\section{Sonuç}

Demokrat Partinin 1950-1954 yıllarında iki seçimi de kazanması muhalefet partilerini güç birliği oluşturmaya itmiştir. Güç birliğini 1957 seçimlerinden sonra hızlandıran muhalefet cephesine karşı Adnan Menderes, Ege illerini kapsayan gezilerinde Vatan Cephesini kurduğunu açıklamıştır. Vatan Cephesi ocaklarına ve Demokrat Parti'ye 1958-1960 yılları arasında Maraşlı vatandaşlarda büyük ilgi göstermiştir. DP il ve ilçe teşkilatının etkili çalışması muhalefet partilerinden de DP'ye ve Vatan Cephesine iltihaklara neden olmuştur. Bu parti değişikliğine Maraş’ta gerek muhalif ocak başkanları gerekse de herhangi bir siyasi partiye bağlı olmayan vatandaşlar aileleriyle birlikle katılmışlardır. Partilerinden istifa

\footnotetext{
104 Demokrasiye Hizmet, 27 Şubat 1960, Say1: 34/2671 s. 1.

105 Halk Postasl, 9 Mart 1960, Say1: 1846, s. 1.

106 Demokrasiye Hizmet, 6 Mart 1960. Say1: 34/2678 s. 1.

107 Demokrasiye Hizmet, 6 Mart 1960 Sayı: 34/2678 s.1; Demokrasiye Hizmet, 8 Mart 1960. Say1: 34/2679 s. 1.

108 Demokrasiye Hizmet, 8 Mart 1960, Say1: 34/2679, s. 1.

109 Demokrasiye Hizmet, 7 Nisan 1960, Say1: 34/2702, s. 1.

110 Demokrasiye Hizmet, 14 May1s 1960 Sayı: 34/2734, s. 1; Demokrasiye Hizmet, 15 May1s 1960, Say1: 34/2735, s. 1; Demokrasiye Hizmet, 17 May1s 1960, Sayı: 34/2736, s.1; Demokrasiye Hizmet, 18 May1s 1960, Say1 34/2737, s. 1; Demokrasiye Hizmet, 19 May1s 1960, Say1: 34/2738 s.1; Demokrasiye Hizmet, 20 Mayıs 1960, Sayı: 34/2739 s. 1.
} 
ederek DP'ye katılan vatandaşlar Maraş'ın yerel gazetelerinde liste halinde yayınlanarak vatandaşa ulaştırılması sağlanmıştır. Özellikle Ocak 1959 yılından itibaren Maraş’ta Vatan Cephesine geçildiğine dair Adnan Menderes'e yüzlerce telgraf gönderilmiştir. Telgrafların çok olması DP'nin veya Vatan Cephesinin Maraş'ta büyük bir etki bıraktığını ortaya koymaktadır. Ayrıca iktidar tarafının muhalefet partileri için yaptığı "yıkıcı", "bozguncu", "nifak", "haçlı birliği”" gibi tanımlamaları halk arasında da yayılmıştır. Özellikle CHP'den istifa ederek DP'ye katılan kişilerin sayıca fazla olması iktidar ve muhalefet arasında çatışma yaratırken Vatan Cephesi ile birlikte siyasi kutuplaşmaya neden olmuştur. Maraş ili içerisinde vatandaşlar arasında Vatan Cephesine kayıt olanlar ve olmayanlar şeklinde ikiye bölünmeler gerçekleşmiştir. Nitekim bu kutuplaşma sadece Maraş ili özelinde değil yurt geneline de yayılmıştır.

DP Maraş İl Başkanlığı dışında Maraş DP Kadın Kolları Başkanlığı kurulmuş, Vatan Cephesine katılımları sağlamak amacıyla çeşitli çalışmalar ve propagandalar yapılmıştır. Cumhuriyet Arşivi belgelerine göre bu çalışmalar neticesinde hem kadın kollarına hem de Vatan Cephesine katılımlar artmıştır. Maraş’ta partilerinden istifa ederek Vatan Cephesine kayıt yaptıran vatandaşlar, durumu Menderes'e telgraf çekerek bildirmiştir. Çekilen telgraflarda en çok eleştirilen muhalefet partileri arasında CHP yer almaktadır. Telgraflardan anlaşılacağı üzere Maraş genelinde Vatan Cephesine ve DP'ye, en çok CHP ve CMP'den geçişlerin yaşandığ görülmektedir. Bu geçişler en çok Göksun ve Elbistan ilçeleri ile bunlara bağlı köylerden gerçekleşirken bu köylerde bulunan muhalefet partisine bağlı ocaklar kapatılıp Demokrat Parti ocağına dönmüştür.

1960 yılında iktidar-muhalefet arasındaki uzlaşılamaz hale gelen kutuplaşma: Ankara ve İstanbul'daki öğrenci olayları, Tahkikat Komisyonunun kurulması ve İsmet İnönü'nün Kayseri ziyaretinde yaşanan olaylara neden olmuştur. Maraş İlinde olduğu gibi yurt genelinde de Vatan Cephesi sonuçları bakımından kutuplaşmayı arttırırken 27 Mayıs askeri müdahalesine giden süreçte önemli bir faktör olmuştur.

\section{Kaynaklar}

\section{Arşiv Belgeleri}

\section{Başbakanlık Cumhuriyet Arşivi (CCA)}

BCA, Fon Kodu: 010. 09. Yer No: 212. 656.1.

BCA, Fon Kodu: 010. 09. Yer No: 218.677.1-142.

BCA, Fon Kodu: 010. 09. Yer No: 218.677.1-141.

BCA, Fon Kodu: 010. 09. Yer No: 218.677.1-433.

BCA, Fon Kodu: 010. 09. Yer No: 218.677.1-429.

BCA, Fon Kodu: 010. 09. Yer No: 218.677.1-428.

BCA, Fon Kodu: 010. 09. Yer No: 218.677.1-139. 
BCA, Fon Kodu: 010. 09. Yer No: 218.677.1-404.

BCA, Fon Kodu: 010. 09. Yer No: 218.677.1-399.

BCA, Fon Kodu: 010. 09. Yer No: 218.677.1-419.

BCA, Fon Kodu: 010. 09. Yer No: 218.677.1-403.

BCA, Fon Kodu: 010. 09. Yer No: 218.677.1-402.

BCA, Fon Kodu: 010. 09. Yer No: 218.677.1-397

BCA, Fon Kodu: 010. 09. Yer No: 218.677.1-395.

BCA, Fon Kodu: 010. 09. Yer No: 218.677.1-392.

BCA, Fon Kodu: 010. 09. Yer No: 218.677.1-135.

BCA, Fon Kodu: 010. 09. Yer No: 218.677.1-134.

BCA, Fon Kodu: 010. 09. Yer No: 218.677.1-133.

BCA, Fon Kodu: 010. 09. Yer No: 218.677.1-132.

BCA, Fon Kodu: 010. 09. Yer No: 218.677.1-131.

BCA, Fon Kodu: 010. 09. Yer No: 218.677.1-130.

BCA, Fon Kodu: 010. 09. Yer No: 218.677.1-137.

BCA, Fon Kodu: 010. 09. Yer No: 218.677.1-129.

BCA, Fon Kodu: 010. 09. Yer No: 218.677.1-212.

BCA, Fon Kodu: 010. 09. Yer No: 218.677.1-204.

BCA, Fon Kodu: 010. 09. Yer No: 218.677.1-205.

BCA, Fon Kodu: 010. 09. Yer No: 218.677.1-349.

BCA, Fon Kodu: 010. 09. Yer No: 218.677.1-348.

BCA, Fon Kodu: 010. 09. Yer No: 218.677.1-347.

BCA, Fon Kodu: 010. 09. Yer No: 218.677.1-345.

BCA, Fon Kodu: 010. 09. Yer No: 218.677.1-344.

BCA, Fon Kodu: 010. 09. Yer No: 218.677.1-343.

BCA, Fon Kodu: 010. 09. Yer No: 218.677.1-340.

\section{Gazeteler}

Vatan, Y11:14, Sayı: 4660, 3 Mayıs 1954.

Vatan, Y1l: 18, Sayı: 5902, 28 Ekim 1957.

Cumhuriyet, Y11: 22, Say1:7682, 7 Ocak 1946.

Cumhuriyet, Y11:22, Say1:7683, 8 Ocak 1946. 
Kahramanyurt, Y11: 10, Say1:2573, 15 Eylül 1958.

Kahramanyurt, Y11: 10, Say1: 2593, 6 Ekim 1958.

Kahramanyurt, Y11: 10, Say1: 2600, 14 Ekim 1958.

Kahramanyurt, Y11: 10, Say1: 2638, 27 Kasim 1958.

Kahramanyurt, Y11: 10, Say1: 2616, 27 Ekim 1958.

Halk Postas1, Y11:5, Sayı: 1288, 9 Mayıs 1958.

Halk Postas1, Y1l: 5, Say1: 1289, 10.May1s 1958.

Halk Postas1, Y11: 5, Sayı: 13083 Nisan 1958.

Halk Postas1, Y11: 6, Sayı: 1517, 17 Şubat 1959.

Halk Postas1, Y11: 5, Say1: 1486, 9 Ocak 1959.

Halk Postas1, Y11: 5, Say1: 1495, 20 Ocak 1959.

Halk Postas1, Y11: 5, Say1: 1502, 28 Ocak 1959,

Halk Postası, Yıl: 5, Sayı: 1507, 3 Şubat 1959.

Halk Postas1, Y11: 6, Say1: 1959, 7 Mayıs 1959.

Halk Postas1, Y11: 6, Sayı: 1583, 15 Mayıs 1959.

Halk Postas1, Y11:6, Say1: 1561, 25 Nisan 1959.

Halk Postası, Y11: 6, Sayı: 1584, 16 Mayıs 1959.

Halk Postası, Y1l: 6, Sayı: 1588, 21 Mayıs 1959.

Halk Postas1, Y11: 6, Sayı: 1591, 25 Mayıs 1959.

Halk Postası, Yı1: 6, Sayı: 1661, 19 Ağustos 1959.

Halk Postas1, Y11: 6, Sayı: 1660, 18 Ağustos 1959.

Halk Postas1, Y11: 6, Say1: 1815, 30 Ocak 1960.

Halk Postası, Yıl: 7, Sayı: 1846, 9 Mart 1960.

Halk Postas1, Y11:7, Say1: 1867, 7 Nisan 1960.

Demokrasiye Hizmet, Y11: 10, Say1: 34/2617, 6 Ocak 1960.

Demokrasiye Hizmet, Y11: 10, Sayı: 34/2633, 13 Ocak 1960.

Demokrasiye Hizmet, Yı1: 10, Say1: 34/2650, 2 Şubat 1960.

Demokrasiye Hizmet, Y11: 10, Sayı: 34/2657, 10 Şubat 1960.

Demokrasiye Hizmet, Y11: 10, Sayı: 34/2667, 23 Şubat 1960.

Demokrasiye Hizmet, Y11: 10, Sayı: 34/2671, 27 Şubat 1960.

Demokrasiye Hizmet, Y11: 10, Say1: 34/2678, 6 Mart 1960.

Demokrasiye Hizmet, Y11: 10, Sayı: 34/2679, 8 Mart 1960. 
Demokrasiye Hizmet, Y11: 10, Say1: 34/2702, 7 Nisan 1960.

Demokrasiye Hizmet, Y11: 10, Say1: 34/2734, 14 May1s 1960.

Demokrasiye Hizmet, Y11: 10, Say1: 34/2735, 15 May1s 1960.

Demokrasiye Hizmet, Y11: 10, Sayı: 34/2736, 17 May1s 1960.

Demokrasiye Hizmet, Y11: 10, Sayı: 34/2737 18 Mayıs 1960.

Demokrasiye Hizmet, Yıl: 10, Say1:34/2738 19 May1s 1960.

Demokrasiye Hizmet, Y11: 10, Sayı: 34/2739 20 Mayıs 1960.

\section{Kitaplar ve Makaleler}

Ahmad, Feroz ve Ahmad, Bedia Turgay, Türkiye'de Çok Partili Politikanın Açıklamalı Kronolojisi (1945-1971), Bilgi Yayınevi, Ankara, 1976.

Arcayürek, Cüneyt, Yeni İktidar, Yeni Dönem (1951-1954), Bilgi Yayınevi, Ankara, 1985, s. 63-67.

Arslan, Zehra, "Vatan Cephesi Davası (Kararname, Savunmalar ve Karar)", History Studies: International Journal of History, Volume 4, Issue 2, July 2012, s.1-37.

Arslan, Zehra, “Trabzon'da Vatan Cephesi (12 Ekim 1958-27 Mayıs 1960)”, Karadeniz Araştırmaları Dergisi, S.129, C.36, Kış 2013, s. 129-148.

Arslan, Zehra, "Siyasilerin Beyanatları Çerçevesinde 27 Mayıs Darbesine Gidiş Süreci (27 Ekim 1957 - 27 Mayıs 1960)”,Türk Dünyası Araştırmaları Dergisi, 2013 / 204, (May1s-Haziran),s.33-82.

Biçici, Mehmet, "Gaziantep'te Vatan Cephesi”, Tarih Okulu Dergisi, (Journal of History School), 44, 2020, s.157- 175.

Bulut, Sedef, "Üçüncü Dönem Demokrat Parti İktidarı (1957-1960): Siyasi Baskılar ve Tahkikat Komisyonu", Gazi Akademik Bakış, C.2, Sayı 4, Yaz 2009,s.125-145.

Burçak, Salim Rıfkı, On Yılın Anıları (1950-1960), Nurol Matbaacılık, Ankara 1998.

Doğaner, Yasemin, Türk Demokrasi Tarihinde Vatan Cephesi, Siyasal Kitapevi Yayınları, Ankara, 2013.

Elif, Ayşe, Kaya, Emre ve Avşar, Zakir, "Demokrat Partinin Sivil Toplum Üzerinden Siyasal İletişim Denemesi: Vatan Cephesi Örneği”, The Journal of Academic Social Science Studies, Volume 6, Issue 2, February 2013, s. 401-402.

Erdoğan, İnce Dilşen, “Güç Birliği Karşısında Adnan Menderes’in Siyasi Manevrası: Vatan Cephesi (Manisa Örneğinde)", Belgi Dergisi, Pamukkale Üniversitesi Atatürk İlkeleri ve İnkılap Tarihi Araştırma ve Uygulama Merkezi Yayını, C. 2, S. 19, Kış 2020, s. 1910-1924.

Eroğul, Cem, Demokrat Parti Tarihi ve İdeolojisi, İmge Kitabevi, 1990.

İnan, Süleyman, Demokrat Parti Dönemi (1950-1960), Yakın Dönem Türk Politik 
Tarihi, An1 Yayıncıl1k, Ankara 2008.

Sarı, Muhammed, "Demokrat Parti Dönemi Basınına Göre İktidar-Muhalefet İlişkileri Açısından 'Vatan Cephesi”, 10. Uluslararası Türk Dünyası Sosyal Bilimler Kongresi, 2012, s. 751-758.

Sunar, İlkay, Demokrat Parti ve Popülizm, CDTA, C.8, İstanbul 1983, s.2076-2086.

Şavkılı, Cengiz ve Akyıldız, Ali, "Demokrat Parti Dönemi Maraş Basını" Kahramanmaraş Sütçü İmam Üniversitesi Sosyal Bilimler Dergisi, S.16, C.2, 2019, s.757776.

Teziç, Erdoğan, 100 Soruda Siyasi Partiler, Gerçek Yayınevi, İstanbul 1976.

Tuna, Iş11, "Uşakta Vatan Cephesi”, Atatürk Araștırma Merkezi Dergisi, S.100, C.35, Güz 2019, s. 621-646.

Tunç, Bilal, "Türk Siyasi Tarihinde Demokrat Parti Uygulamalarından Vatan Cephesinin Sakarya'daki Yansimaları", Current Research in Social Sciences, Cilt 3, Say1 3, Ocak 2017, 154-168.

Uyar, Hakkı, Türk Siyasal Yaşamında Cepheleşmelere Bir Örnek Vatan Cephesi, Büke Yayınları, İzmir 2001.

Yeşil, Ahmet, Türkiye'de Çok Partili Siyasi Hayata Geçiş, Kültür Bakanlığı, Ankara, 2001.

Yıldırmaz, Sinan, "Vatan Cephesi: Demokrat Parti'nin Politik Meşruiyet Krizi ve Toplumsal Muhalefeti Kontrol Altına Alma Çabası", Türkiye'de Siyasal Muhalefet 19231980 Makaleler, Der. Ayşegül Komsuoğlu, Bengi Yayınevi, İstanbul 2008, s. 173-206.

Yıldırmaz, Sinan, "1950 Seçimleri ve Propaganda", Yakın Dönem Türkiye Araştırmaları, T.C. İstanbul Üniversitesi Atatürk İnkılap Tarihi Dergisi, Sayı:6, Y11:3/ 2004, s. 131-157.

Yücel, Mustafa Serhan, Demokrat Parti, Ülke Kitapları, İstanbul 2001.

Zürcher, Jan Eric, Modernleşen Türkiye'nin Tarihi, Çev. Yasemin Saner Gönen, İletişim Yayınları, İstanbul 1995.

\section{Tezler}

Aslan, Emel, Türkiye'nin İç Siyasetinde Demokrat Parti (1950-1960), (Basılmamış Yüksek Lisans Tezi), Ahi Evran Üniversitesi Sosyal Bilimler Enstitüsü, Kırşehir 2014.

Aydın, Ayşe, Celal Bayar Dönemi Genel Seçimleri ve TBMM (1950-1960), (Basılmamış Doktora Tezi) Gazi Üniversitesi Sosyal Bilimler Enstitüsü, Ankara, 2010.

Yetim, Fahri, Ulus ve Zafer Gazetelerinin Karşılaştırmalı İncelemeleri (1957-1960), (Basılmamış Doktora Tezi), Gazi Üniversitesi Sosyal Bilimler Enstitüsü, Ankara 2006.

Küçükpınar, Aliye, Maraş Basınında Demokratik Parti (1946-1960), (Basılmamış Yüksek Lisans Tezi) Kahramanmaraş Sütçü İmam Üniversitesi Sosyal Bilimler Enstitüsü, 
Kahramanmaraş 2019.

Tokmak, Mustafa, Basın-İktidar İlişkileri Çerçevesinde Demokrat Parti ve Ankara Radyosu, (Basılmamış Yüksek Lisans Tezi), Hacettepe Üniversitesi Atatürk İlkeleri ve İnkılap Tarihi Enstitüsü, Ankara, 2007.

\section{Elektronik Ortam}

http://www.ysk.gov.tr/tr/1950-1977-yillari-arasi-milletvekili-genel-secimleri/3007 (Erişim Tarihi: 03.04.2020).

Ek 1

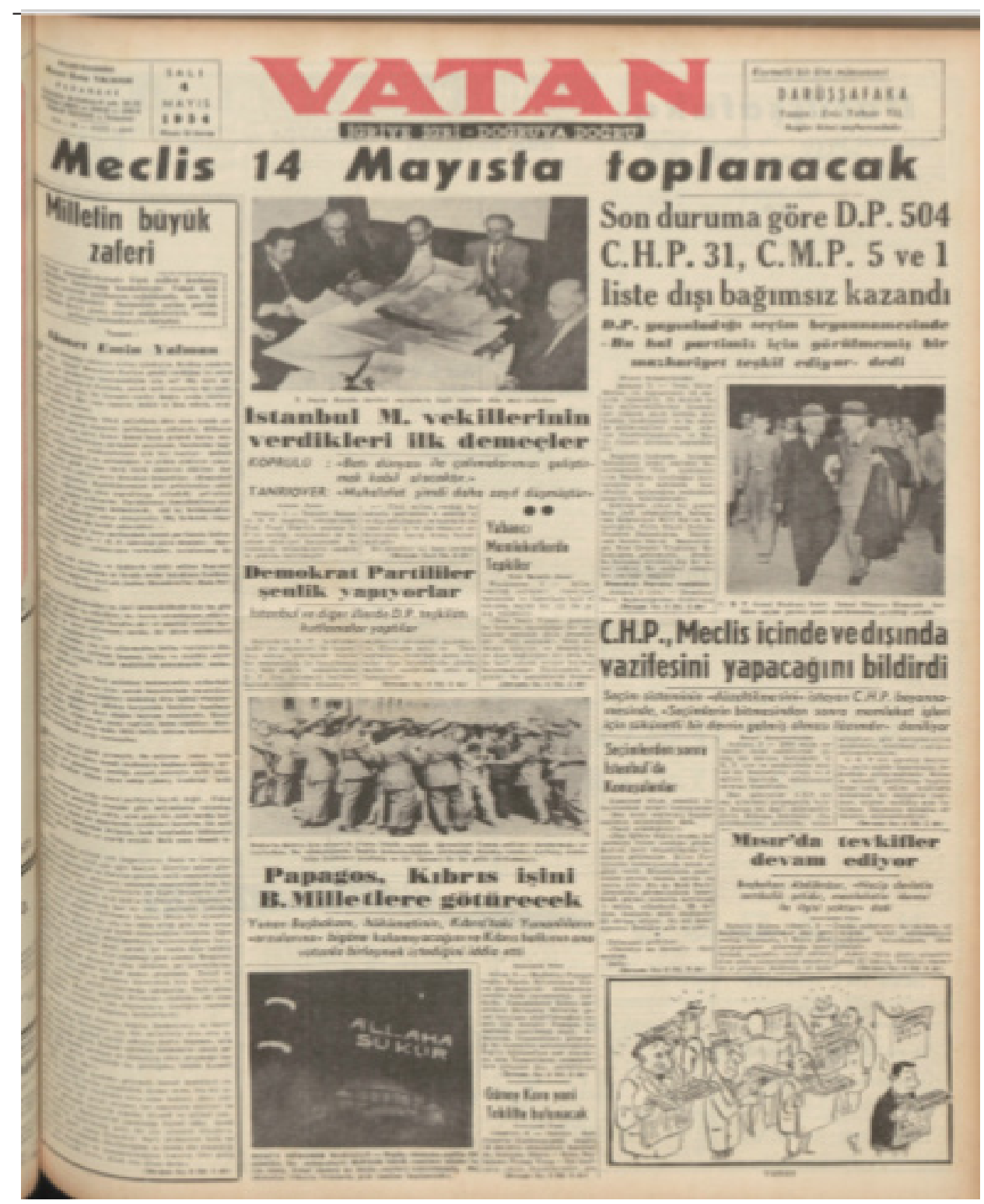

Vatan, 4 Mayis 1954 
Ek 2

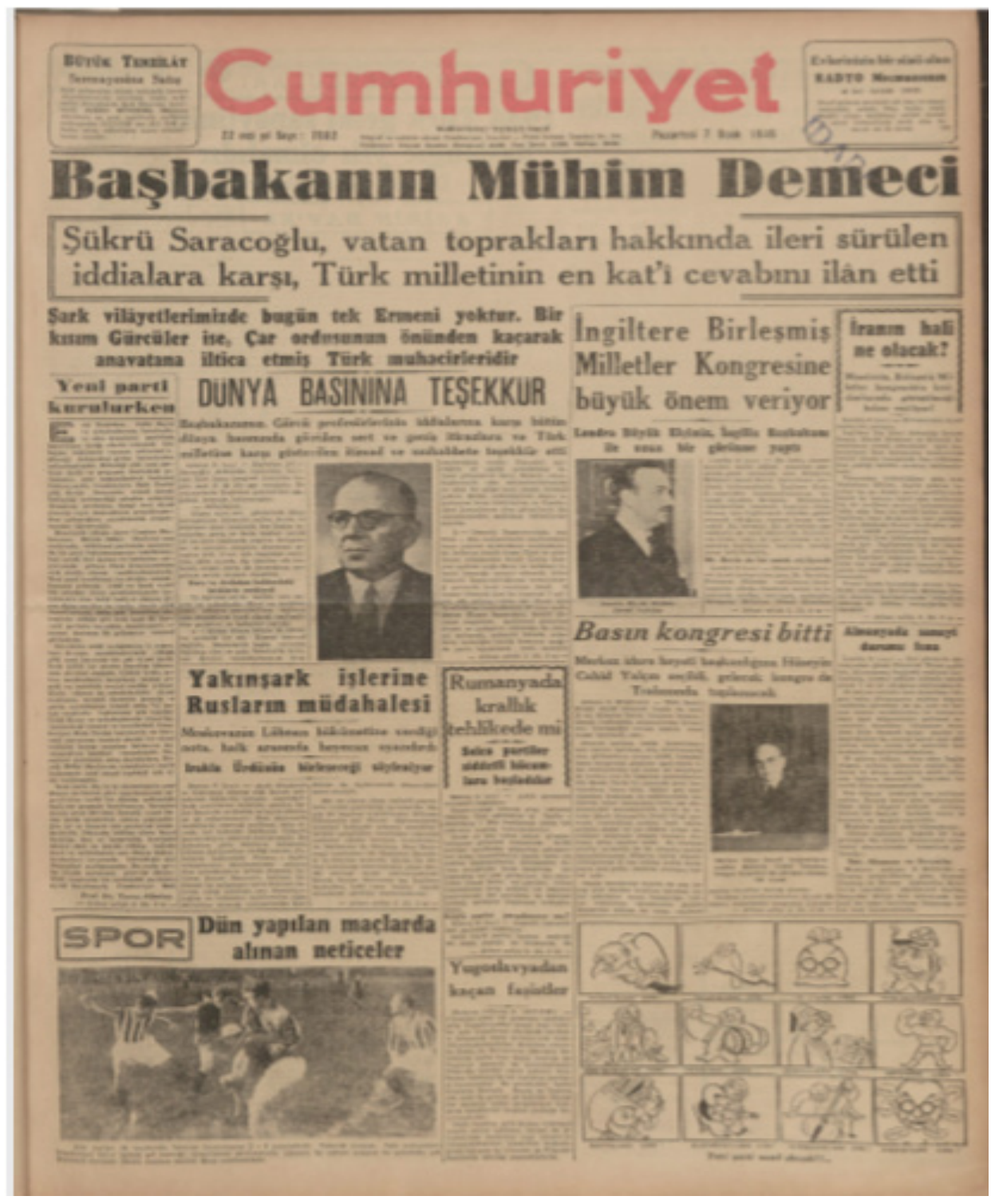

Cumhuriyet, 7 Ocak 1946 


\section{Ek 3}

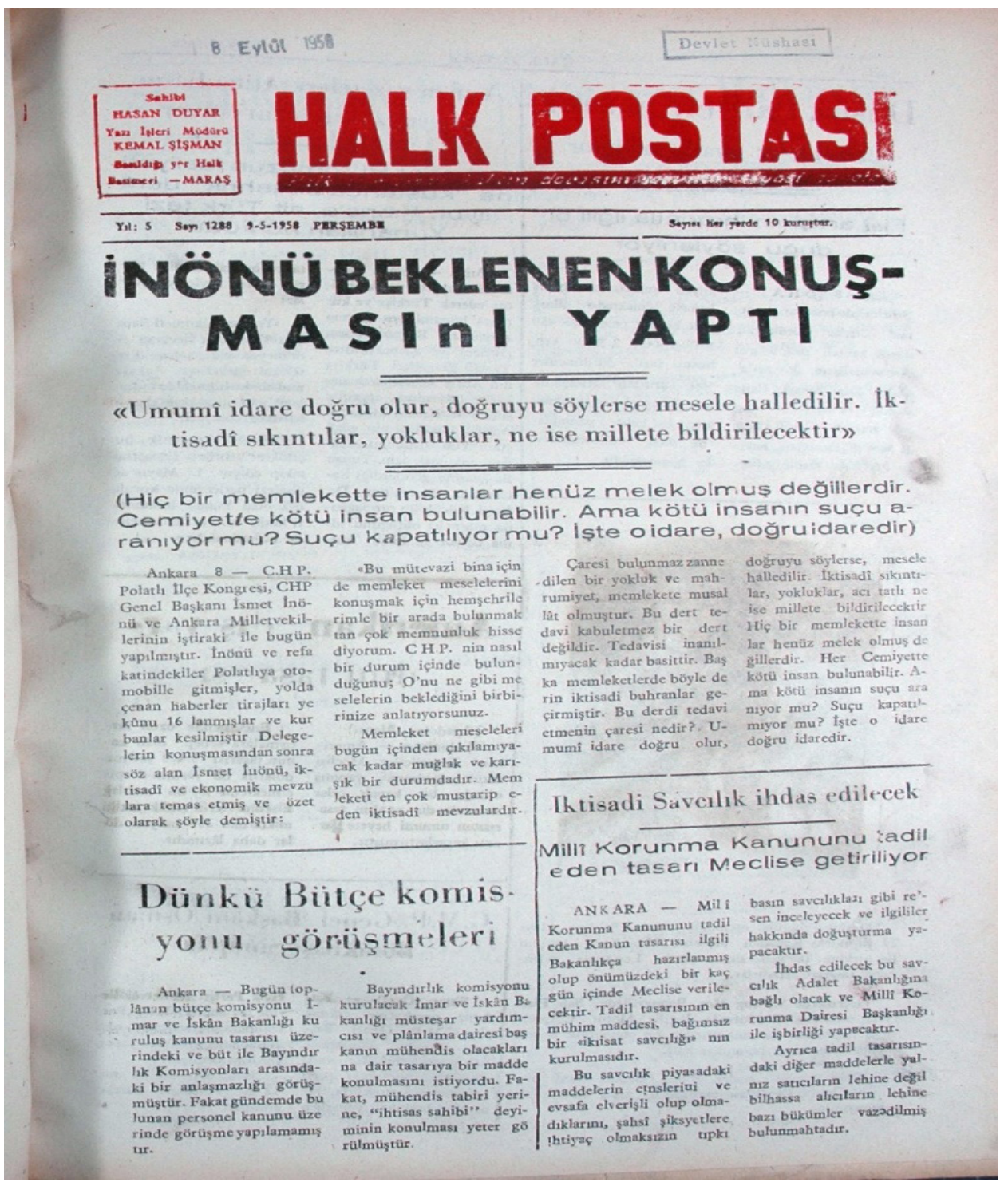

Halk Postası, 9 Mayıs 1958 
Ek 4

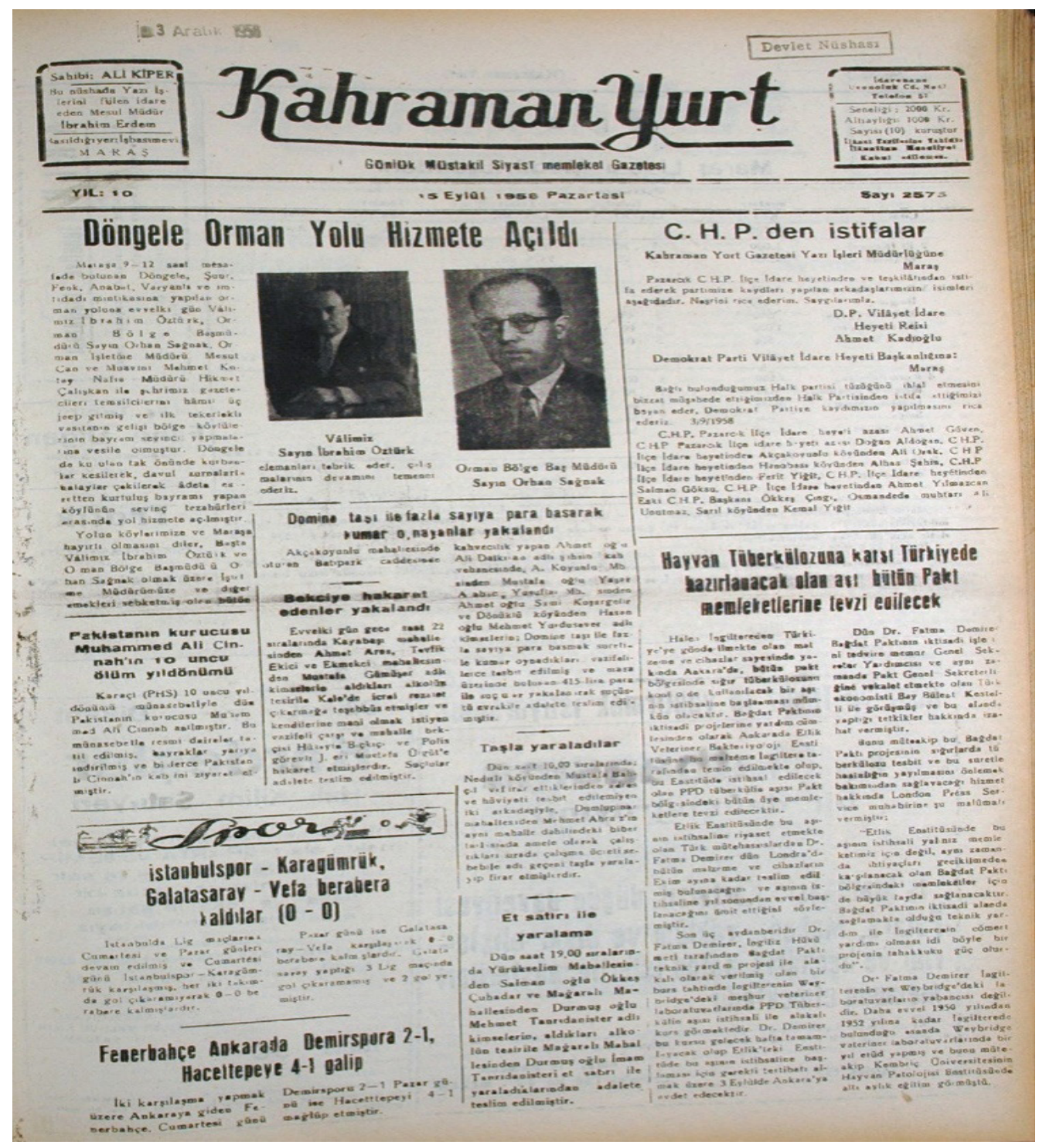

Kahramanyurt, 15 Eylül 1958 
Tarih ve Gelecek Dergisi, Haziran 2020, Cilt 6, Sayl 2

\section{Ek 5}

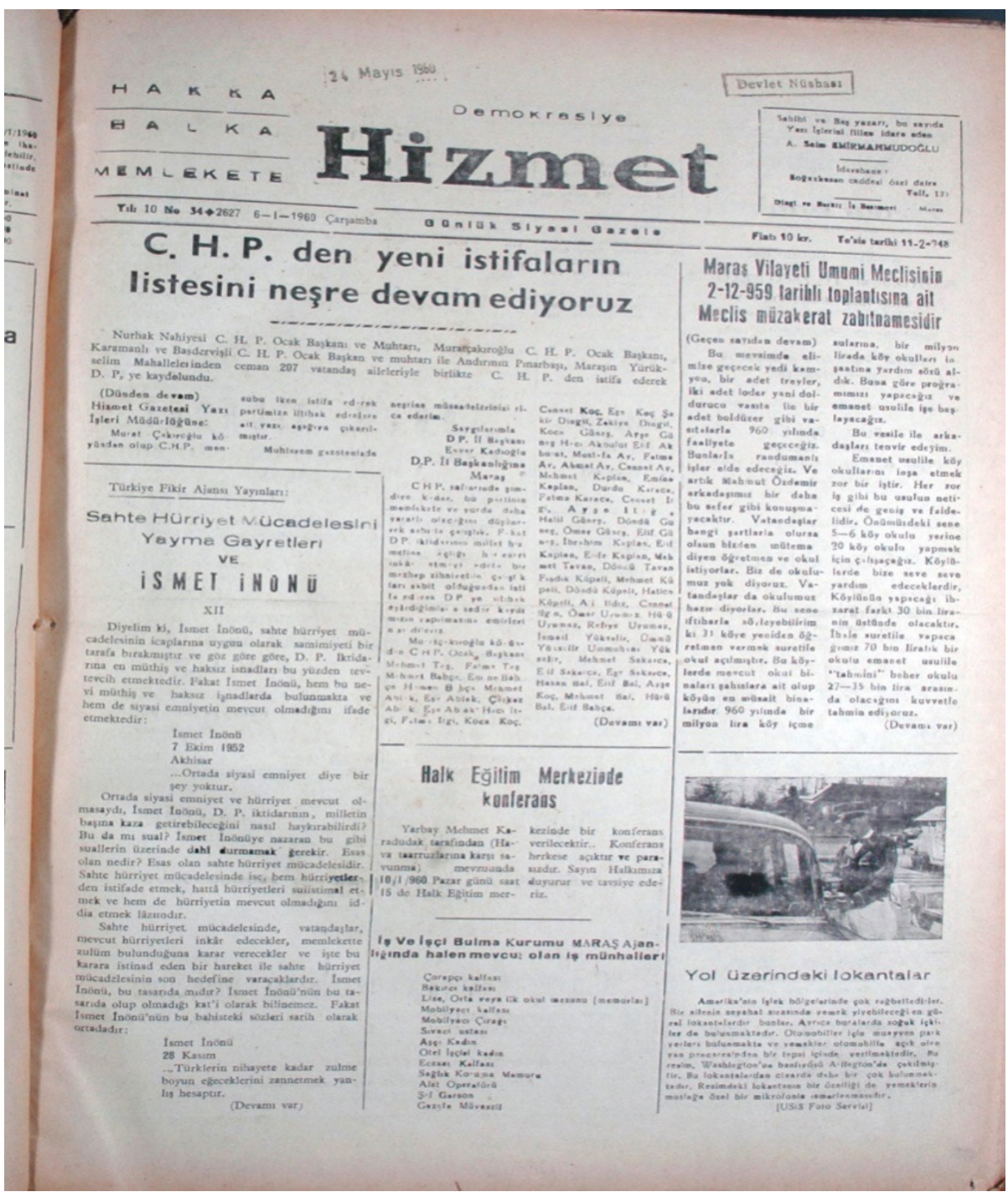

Demokrasiye Hizmet, 6 Ocak 1960 